\title{
Thin Film Mixed Matrix Hollow Fiber Membrane Fabricated by Incorporation of Amine Functionalized Metal-Organic Framework for $\mathrm{CO}_{2} / \mathrm{N}_{2}$ Separation
}

\author{
Guoqiang Li ${ }^{1}$, Wojciech Kujawski ${ }^{1,2, *} \mathbb{D}$, Katarzyna Knozowska ${ }^{1}$ and Joanna Kujawa ${ }^{1}(\mathbb{D}$ \\ 1 Department of Physical Chemistry and Physical Chemistry of Polymers, Faculty of Chemistry, Nicolaus \\ Copernicus University in Toruń, 7 Gagarina Street, 87-100 Torun, Poland \\ 2 Moscow Engineering Physics Institute, National Research Nuclear University MEPhI, 31 Kashira Hwy, \\ 115409 Moscow, Russia \\ * Correspondence: kujawski@chem.umk.pl; Tel.: +48-56-6114517
}

\section{check for} updates

Citation: Li, G.; Kujawski, W.; Knozowska, K.; Kujawa, J. Thin Film Mixed Matrix Hollow Fiber Membrane Fabricated by Incorporation of Amine Functionalized Metal-Organic Framework for $\mathrm{CO}_{2} / \mathrm{N}_{2}$ Separation Materials 2021, 14, 3366. https:// doi.org/10.3390/ma14123366

Academic Editor: Anastasios J. Tasiopoulos

Received: 17 May 2021

Accepted: 15 June 2021

Published: 17 June 2021

Publisher's Note: MDPI stays neutral with regard to jurisdictional claims in published maps and institutional affiliations.

Copyright: (c) 2021 by the authors. Licensee MDPI, Basel, Switzerland. This article is an open access article distributed under the terms and conditions of the Creative Commons Attribution (CC BY) license (https:// creativecommons.org/licenses/by/ $4.0 /)$.

\begin{abstract}
Membrane separation technology can used to capture carbon dioxide from flue gas. However, plenty of research has been focused on the flat sheet mixed matrix membrane rather than the mixed matrix thin film hollow fiber membranes. In this work, mixed matrix thin film hollow fiber membranes were fabricated by incorporating amine functionalized UiO-66 nanoparticles into the Pebax ${ }^{\circledR} 2533$ thin selective layer on the polypropylene (PP) hollow fiber supports via dipcoating process. The attenuated total reflection-Fourier transform infrared (ATR-FTIR), scanning electron microscope (SEM), energy-dispersive X-ray spectroscopy (EDX) mapping analysis, and thermal analysis (TGA-DTA) were used to characterize the synthesized $\mathrm{UiO}-66-\mathrm{NH}_{2}$ nanoparticles. The morphology, surface chemistry, and the gas separation performance of the fabricated Pebax ${ }^{\circledR}$ 2533-UiO-66- $\mathrm{NH}_{2}$ /PP mixed matrix thin film hollow fiber membranes were characterized by using SEM, ATR-FTIR, and gas permeance measurements, respectively. It was found that the surface morphology of the prepared membranes was influenced by the incorporation of UiO-66 nanoparticles. The $\mathrm{CO}_{2}$ permeance increased along with an increase of UiO-66 nanoparticles content in the prepared membranes, while the $\mathrm{CO}_{2} / \mathrm{N}_{2}$ ideal gas selectively firstly increased then decreased due to the aggregation of UiO-66 nanoparticles. The Pebax ${ }^{\circledR}$ 2533-UiO-66- $\mathrm{NH}_{2} / \mathrm{PP}$ mixed matrix thin film hollow fiber membranes containing $10 \mathrm{wt} \% \mathrm{UiO}-66$ nanoparticles exhibited the $\mathrm{CO}_{2}$ permeance of 26 GPU and $\mathrm{CO}_{2} / \mathrm{N}_{2}$ selectivity of 37 .
\end{abstract}

Keywords: thin film hollow fiber membranes; amine functionalized nanoparticles $\mathrm{UiO}-66-\mathrm{NH}_{2}$; mixed matrix membranes (MMMs); $\mathrm{CO}_{2} / \mathrm{N}_{2}$ separation

\section{Introduction}

Global warming resulted from greenhouse gas has created serious consequence for the environment, e.g., melting glaciers. In comparison with other greenhouse gases, $\mathrm{CO}_{2}$ is one of the important contributors to global warming [1]. $\mathrm{CO}_{2}$ emission increases significantly every year due to the rapid development of industry and the more intensive human activities. The flue gas released by power plant due to the usage of fossil fuels is the main source of $\mathrm{CO}_{2}$ emission [2]. Therefore, the separation of $\mathrm{CO}_{2}$ from flue gas mixture to mitigate the $\mathrm{CO}_{2}$ emission plays an important role in the environment protection and the sustainable development of the industry [3]. Membrane separation technology, physical and chemical adsorption, and cryogenic separation have been used in the $\mathrm{CO}_{2}$ capture process $[1,4,5]$.

Membrane separation technology is widely considered as an alternative to the traditional intensively energy-consuming technologies for $\mathrm{CO}_{2}$ separation [6]. Various types of membrane have been used for $\mathrm{CO}_{2}$ capture from flue gas mixture, such as polymeric membranes [7,8], inorganic membranes [9], and mixed matrix membranes (MMMs) [10-12]. 
Pebax ${ }^{\circledR}$ materials are used for MMMs fabrication because of their advantages, e.g., desirable separation performance and high processability [13]. They are good candidates for polymeric membrane matrix for $\mathrm{CO}_{2} / \mathrm{N}_{2}$ separation due to their desirable $\mathrm{CO}_{2}$ permeance, high ideal selectivity, and tunability of gas separation properties via the incorporation of nanofillers [14]. Pebax ${ }^{\circledR} 2533$ shows higher $\mathrm{CO}_{2}$ permeability with desirable $\mathrm{CO}_{2} / \mathrm{N}_{2}$ selectivity [15]. Therefore, Pebax ${ }^{\circledR} 2533$ was chosen as the polymer matrix for the preparation of thin film mixed matrix hollow fiber membranes in this work. Thin film Pebax ${ }^{\circledR}$ 2533/polyetherimide (PEI) composite hollow fiber membranes were fabricated via dip coating method and assembled into a lab-scale hollow fiber module for $\mathrm{CO}_{2} / \mathrm{N}_{2}$ separation [13]. In the pure gas permeance test, the prepared membranes exhibited $\mathrm{CO}_{2}$ and $\mathrm{N}_{2}$ permeances equal to 48 and $1.6 \mathrm{GPU}$, respectively, at $23^{\circ} \mathrm{C}$ and $790 \mathrm{kPa}$, while the $\mathrm{CO}_{2}$ and $\mathrm{N}_{2}$ permeances are 36 and $1.7 \mathrm{GPU}$, respectively, in the gas mixture permeance test under the same testing conditions. The $\mathrm{CO}_{2}$ permeance from gas mixture test was $12 \mathrm{GPU}$ lower than that from pure gas test. However, the $\mathrm{N}_{2}$ permeance in both cases are practically the same [13].

MMMs containing metal-organic framework (MOF) have been intensively studied to improve the comprehensive gas separation properties of membranes. This is because MOFs possess high surface area, high packing capacity, tunable porosity and pore size, chemical functionality, and enormous varieties, which endows them huge advantages for the incorporation into polymer matrix [16-18]. MOFs are more intensively used in MMMs for various gas separation processes than other porous fillers [5].

MOFs such as the zeolitic imidazolate framework (ZIF) [17-19], Materials Institute Lavoisier (MIL) [20], and University in Oslo (UiO-66) [21,22] are commonly used for the preparation of MMMs for gas separation. Gao et al. [19] incorporated ZIF-7-NH 2 , ZIF-7$\mathrm{OH}$, and ZIF-7- $\mathrm{CH}_{3} \mathrm{OH}$ into Pebax ${ }^{\circledR} 2533$ matrix to fabricate MMMs. The $\mathrm{CO}_{2}$ adsorption properties of MMMs was enhanced due to the introduction of functional groups in ZIF-7 framework. All the prepared MMMs showed better $\mathrm{CO}_{2} / \mathrm{N}_{2}$ separation performance than the pristine Pebax ${ }^{\circledR}$ membranes. The MMM containing $14 \mathrm{wt} \%$ ZIF-7-OH particles exhibited high $\mathrm{CO}_{2}$ permeability equal to 273 Barrer and $\mathrm{CO}_{2} / \mathrm{N}_{2}$ selectivity equal to 38 , which in comparison to the pristine Pebax ${ }^{\circledR}$ membrane increased by 60 and $145 \%$, respectively. Jameh et al. [23] modified ZIF-8 nanoparticles with ethylenediamine (ED) and incorporated them into Pebax ${ }^{\circledR} 1074$ matrix to fabricate $\mathrm{MMMs}$ for $\mathrm{CO}_{2}$ capture. The authors found that the $\mathrm{CO}_{2}$ adsorption capacity of MMM containing ED modified ZIF-8 was higher than that containing ZIF-8. Consequently, $\mathrm{CH}_{4}$ and $\mathrm{CO}_{2}$ permeabilities of the ZIF-8/Pebax ${ }^{\circledR}$ MMMs are 9.39 and 134 Barrer, respectively, while for the ED-ZIF-8/Pebax ${ }^{\circledR}$ MMMs, the $\mathrm{CH}_{4}$ and $\mathrm{CO}_{2}$ permeabilities were 14.2 and 344 Barrer, respectively. Dai et al. [24] incorporated ZIF-8 into polyetherimide (PEI) matrix to prepare dual layer mixed matrix hollow fiber membranes via dry jet-wet spinning technique. It was found that presence of ZIF-8 increased the $\mathrm{CO}_{2}$ permeance and $\mathrm{CO}_{2} / \mathrm{N}_{2}$ ideal selectivity from $13 \mathrm{GPU}$ and 34 to 21 GPU and 39, respectively, in comparison to pure PEI hollow fiber membranes. Etxeberria-Benavides et al. [25] prepared polybenzimidazole (PBI) mixed matrix hollow fiber membranes containing ZIF-8 for $\mathrm{H}_{2} / \mathrm{CO}_{2}$ separation. The prepared membranes showed high $\mathrm{H}_{2}$ permeance of $107 \mathrm{GPU}$ at 7 bar and $70{ }^{\circ} \mathrm{C}$ in comparison with $65 \mathrm{GPU}$ of pristine PBI hollow fiber membranes. While the $\mathrm{H}_{2} / \mathrm{CO}_{2}$ selectivity was constant. For the mixed gas permeation, the improvement of $\mathrm{H}_{2} / \mathrm{CO}_{2}$ separation performance for PBI mixed matrix hollow fibers is hindered at high pressure around 30 bar because of the $\mathrm{CO}_{2}$ adsorption in ZIF-8, which blocks the $\mathrm{H}_{2}$ transport [25]. Song et al. [20] prepared Pebax ${ }^{\circledR}$ 1657/MIL-101 and Pebax ${ }^{\circledR}$ 1657/NH $\mathrm{NH}_{2}$-MIL-101 MMMs for $\mathrm{CO}_{2} / \mathrm{N}_{2}$ separation under sub-ambient condition. Authors found that the Pebax ${ }^{\circledR} 1657 / \mathrm{NH}_{2}$-MIL-101 MMM possesses higher $\mathrm{CO}_{2} / \mathrm{N}_{2}$ selectivity equal to 95.6 comparing to $\mathrm{CO}_{2} / \mathrm{N}_{2}$ selectivity equal to 89.4 for Pebax ${ }^{\circledR} 1657 /$ MIL-101 MMM. This is because the amino-modified MIL-101 introduced $-\mathrm{NH}_{2}$ group possessing higher affinity to $\mathrm{CO}_{2}$. Therefore, the solubility and adsorption capacity of $\mathrm{CO}_{2}$ in MMMs were improved [20]. 
The preparation of flat sheet MMMs containing UiO-66 and $\mathrm{UiO}-66-\mathrm{NH}_{2}$ for gas separation has been also studied [14,21,22]. Shen et al. [14] prepared UiO-66/Pebax ${ }^{\circledR} 1657$ and UiO-66- $\mathrm{NH}_{2} /$ Pebax ${ }^{\circledR} 1657$ flat sheet $\mathrm{MMMs}$ for $\mathrm{CO}_{2} / \mathrm{N}_{2}$ separation. It was found that the UiO-66- $\mathrm{NH}_{2}$ nanoparticles showed higher affinity to carbon dioxide than UiO-66. The dispersibility of nanoparticles in the polymer matrix was improved due to the enhanced hydrogen bonding between fillers and polymer chains. With MOF loading of $10 \mathrm{wt} \%$, UiO-66- $\mathrm{NH}_{2}$-Pebax ${ }^{\circledR} 1657 \mathrm{MMM}$ showed higher $\mathrm{CO}_{2} / \mathrm{N}_{2}$ selectivity and slightly lower $\mathrm{CO}_{2}$ permeability than those of UiO-66-Pebax ${ }^{\circledR} 1657$ membrane [14]. Chuah et al. [21] investigated $\mathrm{CO}_{2} / \mathrm{N}_{2}$ separation performance of polyimide-based MMMs containing UiO-66 possessing different functional groups $\left(-\mathrm{HN}_{2},-\mathrm{Br},-(\mathrm{OH})_{2}\right)$. It was found that the functionalized UiO-66 in MMMs can effectively increase the $\mathrm{CO}_{2}$ diffusivity while suppressing $\mathrm{N}_{2}$ adsorption [21]. In the above examples, the UiO-66 nanoparticles with various functional groups are synthesized by using pre-synthetic functionalization. It is believed that the further functionalization of $\mathrm{UiO}-66-\mathrm{NH}_{2}$ by using post-synthetic functionalization method can further tune the properties of $\mathrm{UiO}-66-\mathrm{NH}_{2}$, such as the $\mathrm{CO}_{2}$ affinity and adsorption capacity, pore size, and surface area. Consequently, the $\mathrm{CO}_{2}$ capture ability of MMMs is enhanced [22]. Jiang et al. [22] modified UiO-66- $\mathrm{NH}_{2}$ with imidazole-2-carbaldehyde (ICA) via amine condensation. After modification, the pore volume and BET (Brunauer-EmmettTeller) area of UiO-66- $\mathrm{NH}_{2}$ were reduced while the $\mathrm{CO}_{2}$ affinity and $\mathrm{CO}_{2} / \mathrm{CH}_{4}$ adsorption selectivity were increased. It was found that when $10 \mathrm{wt} \%$ modified UiO-66- $\mathrm{NH}_{2}$ was incorporated into Matrimid ${ }^{\circledR}$ membranes, the high $\mathrm{CO}_{2} / \mathrm{CH}_{4}$ selectivity of 64.7 was obtained, which is $40 \%$ higher than the membranes containing $\mathrm{UiO}-66-\mathrm{NH}_{2}$. As aforementioned, the presence of amine groups improved the $\mathrm{CO}_{2}$ adsorption capacity for $\mathrm{UiO}-66-\mathrm{NH}_{2}$, resulting in higher $\mathrm{CO}_{2}$ solubility of MMMs, consequently, the higher $\mathrm{CO}_{2} / \mathrm{N}_{2}$ selectivity. Moreover, $\mathrm{UiO}-66-\mathrm{NH}_{2}$ shows high compatibility with polymer matrix due to the hydrogen bonding between Pebax ${ }^{\circledR}$ chains and UiO-66- $\mathrm{NH}_{2}$. Hence, $\mathrm{UiO}-66-\mathrm{NH}_{2}$ was incorporated into Pebax ${ }^{\circledR} 2533$ matrix to improve the gas separation properties of thin film mixed matrix hollow fiber membranes in this work.

Microporous polypropylene hollow fiber membranes are suitable to be used as a support for the fabrication of composite hollow fiber membranes due to their desirable properties, e.g., high void volumes, well-controlled porosity, chemical inertness, good mechanical strength, and low cost [26]. Therefore, polypropylene hollow fibers were used as supports for the preparation of thin film mixed matrix hollow fiber membranes in this work.

Hollow fiber membranes have a promising future in various gas separation processes due to their advantages, e.g., high packing density and a self-supporting structure [6,7]. However, the flat sheet MMMs have been intensively studied since the incorporation of fillers, e.g., MOF particles can significantly enhance the gas separation performance of polymeric membranes. Therefore, it is highly necessary to investigate the formation of a selective layer containing filler e.g., MOF particles on the hollow fiber support and their gas separation performance. In this work, the main objective is to develop thin film mixed matrix hollow fiber membranes by incorporating UiO-66- $\mathrm{NH}_{2}$ filler into the Pebax ${ }^{\circledR} 2533$ selective layer. The effect of UiO-66- $\mathrm{NH}_{2}$ filler on the morphology, surface chemistry, and $\mathrm{CO}_{2} / \mathrm{N}_{2}$ separation performance of the prepared thin film mixed matrix hollow fiber membranes will be investigated.

\section{Experimental}

\subsection{Materials}

Polypropylene (PP) hollow fibers were kindly provided by Faculty of Chemical and Processing Engineering, Warsaw University of Technology (Warsaw, Poland). The PP hollow fibers were prepared via a dry-jet-wet spinning process, using a laboratory made setup. The PP hollow fibers possessed outer diameter of $2.6 \mathrm{~mm}$, internal diameter of $1.8 \mathrm{~mm}$, average pore size of $0.3 \mu \mathrm{m}$, and porosity of $50-60 \%$ [27]. Pebax ${ }^{\circledR} 2533$ was 
provided by Arkema (Colombes, France). Pebax ${ }^{\circledR} 2533$ consists of poly(ethylene oxide)PEO block ( $80 \mathrm{wt} \%$ ) and polyamide-PA-12 block (20 wt $\%)$.

Zirconylchloride octahydrate was supplied by Acbr GmbH (Karlsruhe, Germany). 2-aminoterephthalic acid and N,N-dimethylformamide (DMF) were purchased from Sigma Aldrich (Poznan, Poland). Ethanol was purchased from Alchem Grupa Sp. z o.o. (Torun, Poland). $\mathrm{CO}_{2}(99.999 \%)$ and $\mathrm{N}_{2}(99.999 \%)$ were purchased from Air Products Sp. z o.o. (Siewierz, Poland). The mixing nozzles and epoxy resin were delivered by Farnell (Warsaw, Poland).

\subsection{UiO-66- $\mathrm{NH}_{2}$ Synthesis}

To synthesize UiO-66- $\mathrm{NH}_{2}, 4.34 \mathrm{~g}$ of 2-aminoterephthalic acid and $7.6 \mathrm{~g}$ of zirconylchloride octahydrate were added into $72 \mathrm{~mL}$ of DMF. The homogeneous mixture was obtained by stirring (Heating magnetic stirrer, VELP Scientifica, Usmate Velate, Italy) and sonication (BANDELIN SONOREX, BANDELIN electronic GmbH \& Co. KG, Berlin, Germany) at room temperature. Then the homogeneous mixture was kept in oven (Memmert $\mathrm{GmbH}+\mathrm{Co} . \mathrm{KG}$, Schwabach, Germany) at $120{ }^{\circ} \mathrm{C}$ for $24 \mathrm{~h}$. Then, the temperature of the mixture decreased to room temperature and centrifuged (High speed centrifuge type 310, Mechanika Precyzyjna, Warsaw, Poland) at $5000 \mathrm{rpm}$ for $15 \mathrm{~min}$. The obtained products were washed three times with DMF and ethanol, respectively. Finally, the obtained products were dried at room temperature and further in the oven at $150{ }^{\circ} \mathrm{C}$ for $4 \mathrm{~h}$.

\subsection{Fabrication of Pristine Pebax/PP and Pebax ${ }^{\circledR}$ 2533-UiO-66- $\mathrm{NH}_{2} / \mathrm{PP}$ Thin Film Mixed Matrix Hollow Fiber Membranes}

To prepare the pristine Pebax ${ }^{\circledR}$ 2533/PP thin film hollow fiber membranes, Pebax ${ }^{\circledR}$ 2533 pellets were added into ethanol $(90 \mathrm{wt} \%) /$ water $(10 \mathrm{wt} \%)$ solvent. After that, the mixture was stirred at $80{ }^{\circ} \mathrm{C}$ for $3 \mathrm{~h}$ to obtain 3 and $6 \mathrm{wt} \%$ polymer solutions. Then, Pebax ${ }^{\circledR} 2533$ solution was cooled down to $25^{\circ} \mathrm{C}$. The dip-coating technique was used for the preparation of the thin Pebax ${ }^{\circledR} 2533$ layer on the shell side of the PP hollow fiber supports. First of all, a $10 \mathrm{~cm}$ long PP hollow fiber was prepared, and one end of the hollow fiber was sealed with epoxy resin. After the solidification of epoxy resin, the other end of the hollow fiber was attached to a metal holder. Then the single PP hollow fiber was vertically immersed into the $3 \mathrm{wt} \%$ Pebax ${ }^{\circledR} 2533$ solution for $1 \mathrm{~min}$ at room temperature. Finally, the Pebax ${ }^{\circledR} 2533$ coated hollow fiber was slowly taken from the coating solution and dried in air for more than $48 \mathrm{~h}$ for solvent evaporation. Afterwards, the second Pebax ${ }^{\circledR}$ 2533 thin layer was formed from $6 \mathrm{wt} \%$ Pebax ${ }^{\circledR} 2533$ solution by using the same dip coating procedure. The preparation of the pristine Pebax ${ }^{\circledR} 2533$ thin film hollow fiber membrane was schematically illustrated in Figure 1A. The ideal selectivity of Pebax ${ }^{\circledR} 2533 / \mathrm{PP}$ hollow fiber membranes fabricated by a single layer coating of 3 or $6 \mathrm{wt} \%$ Pebax ${ }^{\circledR} 2533$ solution was very low (Table S1), indicating the formation of defective Pebax ${ }^{\circledR} 2533$ layer. Therefore, a two-step coating process by using two different concentrations of Pebax ${ }^{\circledR} 2533$ solution was applied in this research.

To prepare the Pebax ${ }^{\circledR}$ 2533-UiO-66- $\mathrm{NH}_{2} / \mathrm{PP}$ thin film mixed matrix hollow fiber membranes, a proper amount of $\mathrm{UiO}-66-\mathrm{NH}_{2}$ particles were firstly dispersed into the ethanol/water solution (90:10 $\mathrm{wt} \% / \mathrm{wt} \%$ ) under continuous stirring for $1 \mathrm{~h}$ at $80^{\circ} \mathrm{C}$. Then 30 min sonication process was applied to the $\mathrm{UiO}-66-\mathrm{NH}_{2}$ suspension for better dispersion of UiO-66- $\mathrm{NH}_{2}$ particles. Afterwards, $10 \%$ of the required amount of Pebax ${ }^{\circledR} 2533$ pellets was added to solvent mixture under continuous stirring for $2 \mathrm{~h}$ at $80^{\circ} \mathrm{C}$. Finally, the rest of Pebax ${ }^{\circledR} 2533$ pellets was dissolved into the solvent mixture under continuous stirring for $12 \mathrm{~h}$ at $80^{\circ} \mathrm{C}$ to obtain $6 \mathrm{wt} \%$ Pebax ${ }^{\circledR} 2533$ solution containing UiO-66- $\mathrm{NH}_{2}$. The dip coating process for the preparation of Pebax ${ }^{\circledR} 2533-\mathrm{UiO}-66-\mathrm{NH}_{2} / \mathrm{PP}$ thin film mixed matrix hollow fiber membranes is the same as for the preparation of pristine Pebax ${ }^{\circledR}$ 2533/PP thin film hollow fiber membranes. The first layer was formed on the PP hollow fiber support from $3 \mathrm{wt} \%$ Pebax ${ }^{\circledR} 2533$ solution, and the second layer was formed from the $6 \mathrm{wt} \%$ Pebax ${ }^{\circledR}$ 
2533 solution containing UiO-66- $\mathrm{NH}_{2}$. The fabrication of the Pebax ${ }^{\circledR} 2533-\mathrm{UiO}-66-\mathrm{NH}_{2} / \mathrm{PP}$ mixed matrix thin film hollow fiber membrane was schematically illustrated in Figure 1B.

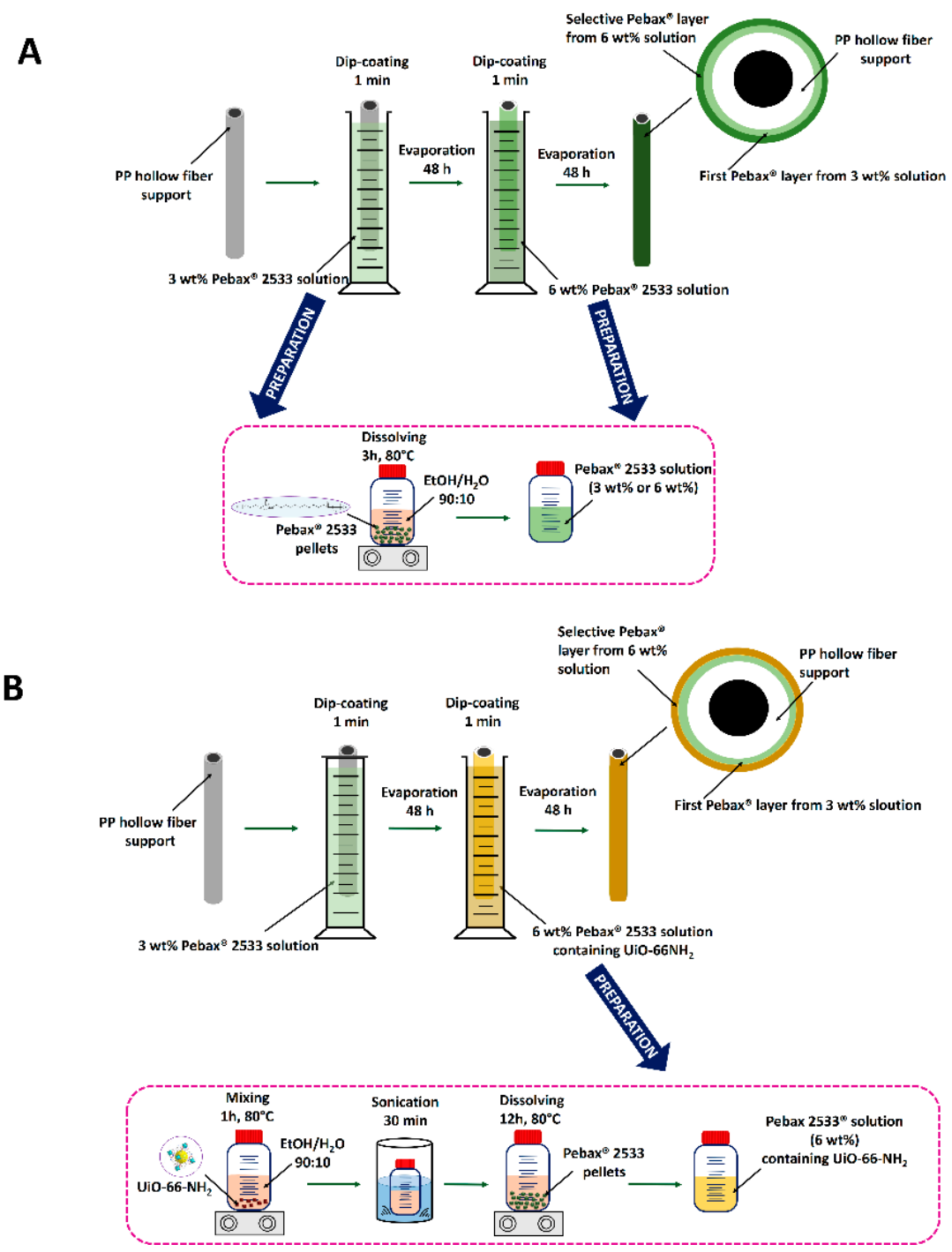

Figure 1. Schematic illustration of the preparation pristine Pebax ${ }^{\circledR} 2533$ thin film hollow fiber membrane (A) and Pebax ${ }^{\circledR}$ 2533-UiO-66- $\mathrm{NH}_{2}$ / PP mixed matrix thin film hollow fiber membrane (B).

\subsection{Characterization}

The morphology and element mapping of the UiO-66- $\mathrm{NH}_{2}$ particles, $\mathrm{PP}$ hollow fibers, Pebax ${ }^{\circledR}$ 2533/PP and mixed matrix Pebax ${ }^{\circledR}$ 2533/PP thin film hollow fiber membranes were analyzed by using scanning electron microscope (SEM) with X-ray spectroscopy (EDX) analysis-Phenom, Generation 5 (Phenom-Word B. V., Eindhoven, The Netherlands). The hollow fiber membranes were fractured in liquid nitrogen (Air Products, Siewierz, Poland) to prepare the samples for the cross-section SEM analysis. The Pebax ${ }^{\circledR} 2533$ layer thickness was measured on SEM pictures by using ImageJ software (version 1.8.0_172, 2020, University of Wisconsin, Madison, WI, USA).

The surface chemistry of UiO-66- $\mathrm{NH}_{2}$ particles, $\mathrm{Pebax}^{\circledR} 2533 / \mathrm{PP}$ and mixed matrix Pebax/PP thin film hollow fiber membranes were analyzed by using FTIR-ATR spectroscopy. The FTIR-ATR spectra were obtained between 500 and $4000 \mathrm{~cm}^{-1}$ by using spectrometer Nicolet iS10 (Thermal Scientific, Waltham, MA, USA). The transmission mode with resolution of $4 \mathrm{~cm}^{-1}$ and 256 scans was applied. The obtained data was analyzed by Omnic 9 software (Version 9.2, 2012, Thermo Fisher Scientific, Waltham, MA, USA). 
The TGA-DTA analyses for UiO-66- $\mathrm{NH}_{2}$ particles were conducted by using TA Instrument type SDT 2960 (TA Instrument, Champaign, IL, USA). The measuring temperature was set in the range of $25-950{ }^{\circ} \mathrm{C}$ under nitrogen atmosphere. The heating rate was $10^{\circ} \mathrm{C} / \mathrm{min}$. The obtained data were analyzed by using TA Universal Analysis software (version: v5.5.24, 2015, TA Instrument, Champaign, IL, USA).

XRD analyses for UiO-66- $\mathrm{NH}_{2}$ particles were conducted by using Philips X'Pert (Malvern Panalytical, Malvern, UK). The transmission mode was applied. The measured $2 \theta$ range was in the range of $5-80^{\circ}$. The $X^{\prime}$ Celerator Scientific detector (Malvern Panalytical, Malvern, UK) with $\mathrm{Cu}$ anode was used.

The nitrogen adsorption/desorption measurements were conducted at $-195.7^{\circ} \mathrm{C}$ via Gemini VI (Micromeritics Instrument Corp., Norcross, GA, USA). All samples were degassed for $6 \mathrm{~h}$ at $110{ }^{\circ} \mathrm{C}$ before the measurements. The BET (Brunauer-Emmett-Teller) model was applied for the calculation of surface area.

\subsection{Gas Permeance Measurements}

To measure the gas permeance of hollow fiber membranes, the hollow fiber membranes should be assembled into the module. The module used for the gas permeance measurements of hollow fiber membranes was designed and assembled by the Membranes and Membrane Techniques Research Group in Nicolaus Copernicus University in Torun, Torun, Poland. All parts of the module were purchased from Swagelok (Torun, Poland) (Figure S1). One hollow fiber with a length of 7-10 cm was assembled into the module. A potting process is needed before the assembling of hollow fiber membrane into the module. The details related to the set-up for gas permeance measurements, and the potting process are described elsewhere [7].

The pure gas $\left(\mathrm{N}_{2}\right.$ and $\left.\mathrm{CO}_{2}\right)$ permeance tests were conducted at 2 bar and $25^{\circ} \mathrm{C}$. Each sample was measured 3 times under stabilized condition for better accuracy. The gas flow rate was measured by using a bubble flow meter (Sigma Aldrich, Poznan, Poland). The permeances $(\mathrm{P} / \mathrm{d})$ of gases were calculated by using Equation $(1)[7,8]$ :

$$
\frac{\mathrm{P}}{\mathrm{d}}=\frac{\mathrm{Q}}{\Delta \mathrm{pA}}=\frac{\mathrm{Q}}{2 \mathrm{n} \pi \mathrm{rl} \Delta \mathrm{p}}
$$

where $\mathrm{P}$ is the permeability (Barrer); $\mathrm{Q}$ is the flux of gas permeation rate $\left(\mathrm{cm}^{3}(\mathrm{STP}) / \mathrm{s}\right) ; \mathrm{d}$ is the thickness of membrane selective layer $(\mathrm{cm})$; $\mathrm{A}$ is the effective membrane area $\left(\mathrm{cm}^{2}\right)$; $\Delta \mathrm{p}$ is the pressure difference across the membrane $(\mathrm{cmHg}) ; \mathrm{r}$ is the outer radius $(\mathrm{cm})$ of hollow fiber; $\mathrm{n}$ is the number of hollow fibers; $\mathrm{P} / \mathrm{d}$ is the gas permeance expressed in GPU (1 GPU $=10^{-6} \mathrm{~cm}^{3}$ (STP) $\mathrm{cm}^{-2} \mathrm{~s}^{-1} \mathrm{cmHg}^{-1}$ ).

The ideal selectivity $\alpha$ was calculated by using Equation $(2)[7,8]$ :

$$
\alpha_{12}=\frac{(\mathrm{P} / \mathrm{d})_{1}}{(\mathrm{P} / \mathrm{d})_{2}}=\frac{\mathrm{P}_{1}}{\mathrm{P}_{2}}
$$

\section{Results and Discussion}

\subsection{Characterization of UiO-66- $\mathrm{NH}_{2}$}

The SEM and EDX results of the synthesized UiO-66- $\mathrm{NH}_{2}$ crystals were shown in Figure 2. The UiO-66- $\mathrm{NH}_{2}$ showed octahedrally rectangular shapes [14]. The particle size of UiO-66- $\mathrm{NH}_{2}$ is around $50-80 \mathrm{~nm}$ (Figure $2 \mathrm{~b}$ ). The elemental composition of synthesized $\mathrm{UiO}-66-\mathrm{NH}_{2}$ was revealed by EDX analysis. $\mathrm{UiO}-66-\mathrm{NH}_{2}$ is composed of $\mathrm{Zr}, \mathrm{C}, \mathrm{O}$, and $\mathrm{N}$ elements (Figure 2c). The EDX results are in good agreement with its crystal structure which consists of $\mathrm{Zr}_{6}$-cluster and 2-aminoterephthalic acid linker. 

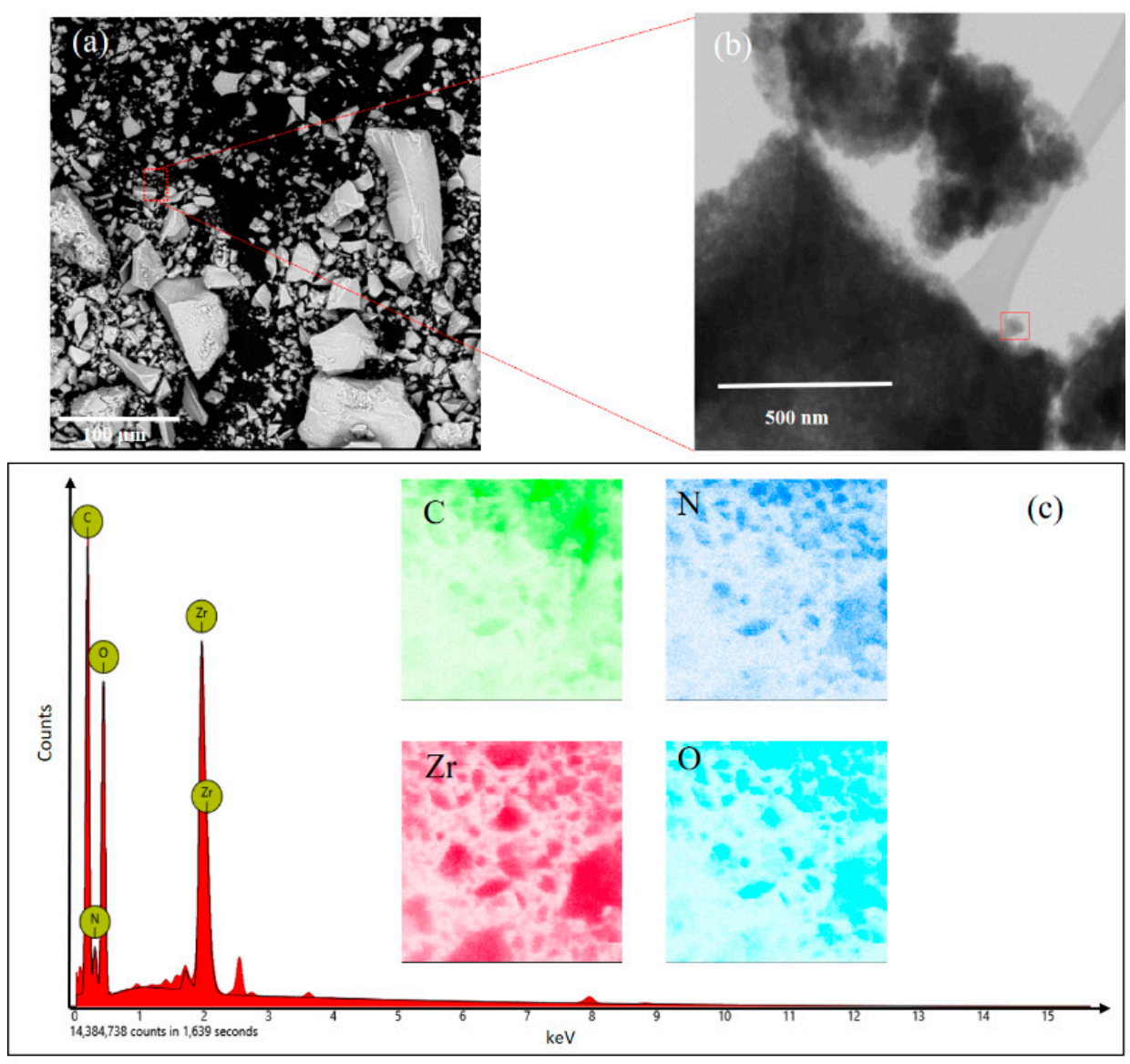

Figure 2. SEM (scanning electron microscope) images of synthesized UiO-66- $\mathrm{NH}_{2}$ particles (a,b). (c) is the corresponding EDX (energy-dispersive X-ray spectroscopy) data and mapping results of the selected area in (a) of UiO-66- $\mathrm{NH}_{2}$ particles.

As it is shown in Figure 3, the FTIR spectra provided more information about the chemical structure of the prepared $\mathrm{UiO}-66-\mathrm{NH}_{2}$ particles. The intensive peak at $1658 \mathrm{~cm}^{-1}$ is ascribed to the stretching vibration of $\mathrm{C}=\mathrm{O}$ group from residual $\mathrm{DMF}$ solvent in the MOF structure [28]. Two characteristic peaks at 3454 and $333 \mathrm{~cm}^{-1}$ can be ascribed to the asymmetric and symmetric stretching vibration of the primary amine group, respectively [29]. Moreover, the peak at $1620 \mathrm{~cm}^{-1}$ can be ascribed to the $\mathrm{N}-\mathrm{H}$ bending vibration. What is more, the $\mathrm{C}-\mathrm{N}$ bonding can be observed at 1257 and $1336 \mathrm{~cm}^{-1}$ due to the stretching vibration of $\mathrm{C}-\mathrm{N}$ bond. The peak at $764 \mathrm{~cm}^{-1}$ can be assigned to the stretching vibration of $\mathrm{Zr}-\mathrm{O}$ bond. The peak at $1435 \mathrm{~cm}^{-1}$ can be related to the $C-C$ stretching vibration in the aromatic ring from the 2-aminoterephthalic acid ligand. Moreover, the peaks at 1381 and $1570 \mathrm{~cm}^{-1}$ can be assigned to the symmetric and asymmetric $\mathrm{C}-\mathrm{O}$ stretching bonds, respectively, resulting from aromatic and carboxylic groups [30].

The TGA and the DTG curves are presented in Figure 4. The DTG curve was plotted as a function of temperature since it can clearly provide information of the transitions of UiO-66- $\mathrm{NH}_{2}$. As it is shown in Figure 4, the TGA and DTG curves of UiO-66- $\mathrm{NH}_{2}$ show a two-step mass loss. The UiO-66- $\mathrm{NH}_{2}$ powder underwent fist-stage mass loss when the temperature increased to $280{ }^{\circ} \mathrm{C}$. This is because the removal of absorbed moisture, residual solvent and the dehyroxylation of the $\mathrm{Zr}_{6} \mathrm{O}_{4}(\mathrm{OH})_{4}$ into $\mathrm{Zr}_{6} \mathrm{O}_{6}$ [28]. The mass lass at this stage is around $40 \%$. The crystal framework decomposition temperature for UiO-66- $\mathrm{NH}_{2}$ is around $380{ }^{\circ} \mathrm{C}$ indicated by the second-stage mass loss. At the second stage of mass loss, the decomposition of amino terephthalic acid ligand occurred and $\mathrm{ZrO}_{2}$ was formed [14]. Finally, when the temperature arrived at $650{ }^{\circ} \mathrm{C}, \mathrm{UiO}-66-\mathrm{NH}_{2}$ nanoparticles showed the largest mass loss around $68 \%$. Cao et al. [31] also found that the decomposition of amino terephthalic acid ligand in $\mathrm{UiO}-66-\mathrm{NH}_{2}$ nanoparticles occurred 
from $380{ }^{\circ} \mathrm{C}$. When the temperature reaches $650{ }^{\circ} \mathrm{C}$, the $\mathrm{UiO}-66-\mathrm{NH}_{2}$ has the largest mass loss of approximately 65\% [31]. The $\mathrm{N}_{2}$ adsorption-desorption isotherm measured at $77 \mathrm{~K}$ was used to determine the specific area and pore structure of $\mathrm{UiO}-66-\mathrm{NH}_{2}$ (Figure 5). The adsorption hysteresis was observed due to the network effects and various forms of pore blocking [32], which could have resulted from the high increasing rate of temperature during the synthesis process. The BET (Brunauer-Emmett-Teller) surface area, adsorption average pore diameter, and BJH (Barrett-Joyner-Halenda) pore volume of the synthesized $\mathrm{UiO}-66-\mathrm{NH}_{2}$ were $349.35 \mathrm{~m}^{2} / \mathrm{g}, 2.35 \mathrm{~nm}$, and $0.49 \mathrm{~cm}^{3} / \mathrm{g}$, respectively. Our results are in good agreement with the earlier reports $[33,34]$.

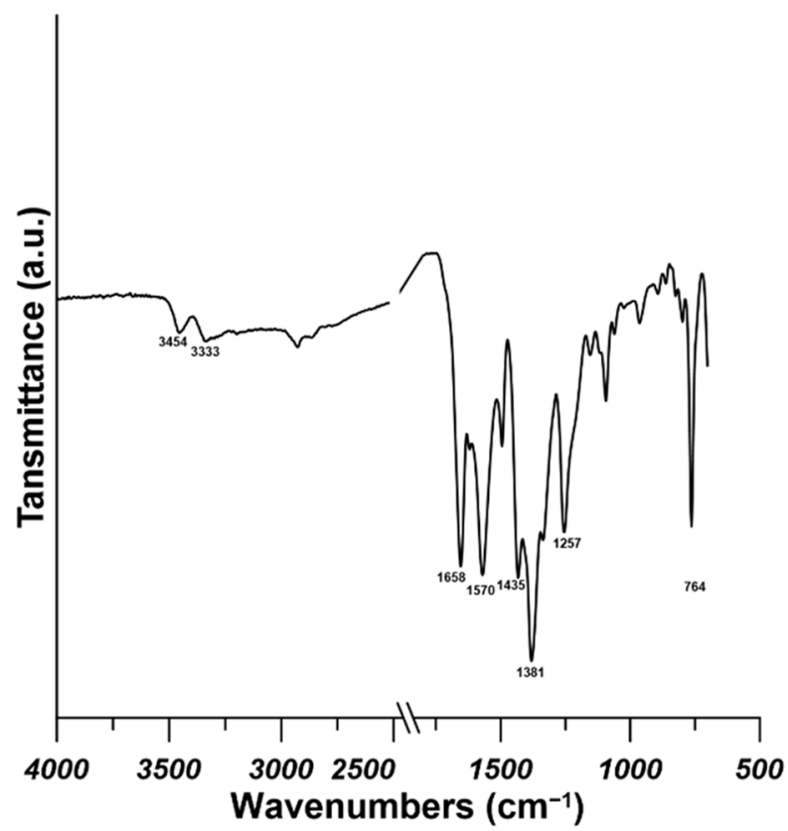

Figure 3. FTIR (fourier transform infrared) spectra of UiO-66- $\mathrm{NH}_{2}$.

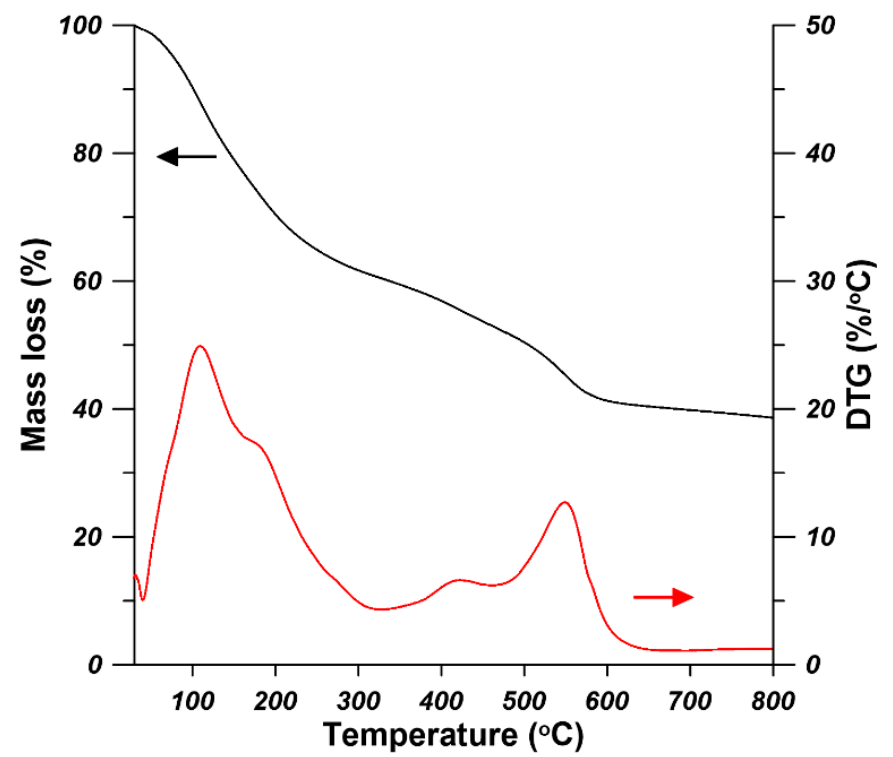

Figure 4. TGA (thermal gravimetric analysis) curves of $\mathrm{UiO}-66-\mathrm{NH}_{2}$. 


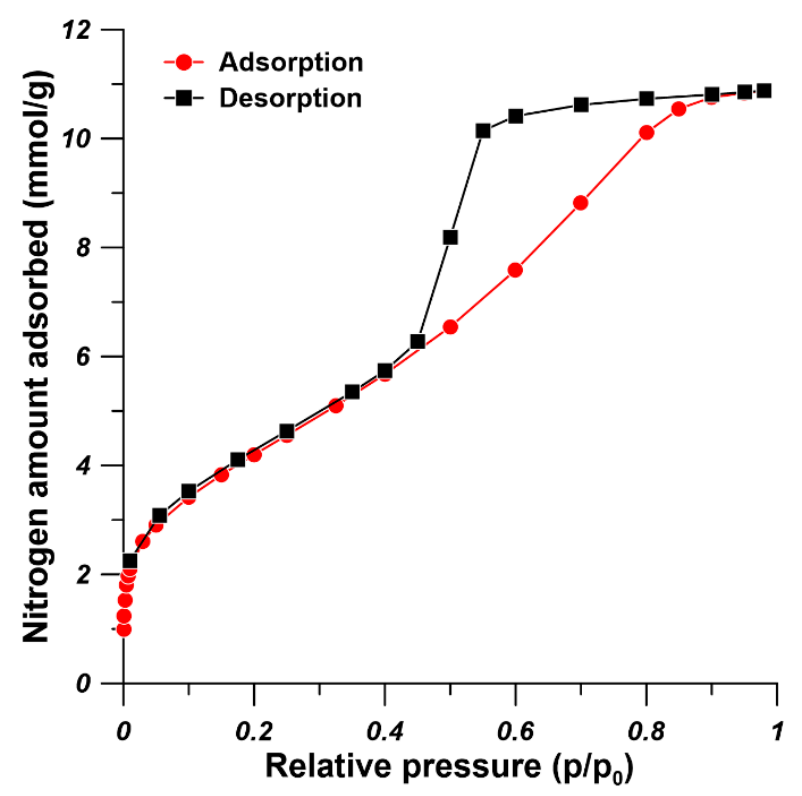

Figure 5. $\mathrm{N}_{2}$ adsorption and desorption curves of $\mathrm{UiO}-66-\mathrm{NH}_{2}$.

The XRD analysis has been performed to prove that $\mathrm{UiO}-66-\mathrm{NH}_{2}$ has been successfully synthesized. The formation of MOF was evidenced by the observation of characteristic intensive peaks at 2 Theta equal to $7.5^{\circ}(111)$ and $8.8^{\circ}$ (002) (Figure 6). The experimental results are in a good accordance to the theoretical diffractogram, calculated based on the single crystal data (Figure 6) (ref code: SURKAT, deposit nr: 1405751) [35] with the implementation of Mercury software (Mercury 4. 2. 0., 2019, Cambridge Crystallographic Data Centre, Cambridge, UK).

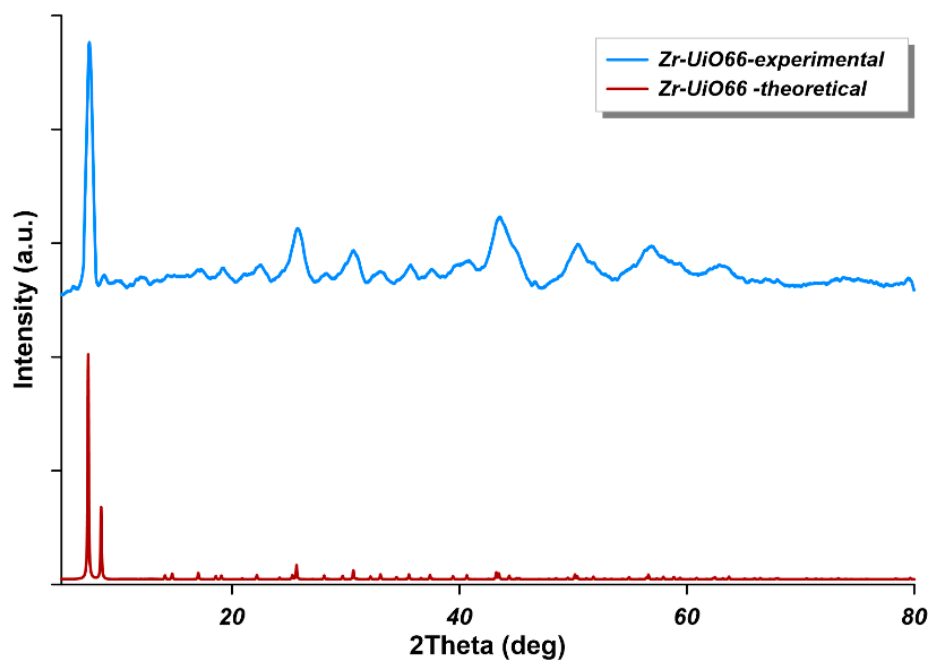

Figure 6. XRD (X-Ray diffraction) pattern of UiO-66- $\mathrm{NH}_{2}$ (the blue curve) and the theoretical XRD pattern of UiO-66 MOF (metal-organic frameworks) (the red curve).

\subsection{Membrane Characterization}

The cross-section SEM and surface images of the polypropylene (PP) hollow fiber support, pristine Pebax ${ }^{\circledR} 2533$ membrane, and thin film mixed matrix hollow fiber membranes were shown in Figure 7. The Pebax ${ }^{\circledR} 2533$ thin layer was successfully coated on the shell side of PP hollow fibers by using a dip-coating method. As it is shown in Figure 7A, the PP hollow fiber supports possess porous structure (A1 and A2) and porous outer surface (A3 and A4). The porosity of PP hollow fiber is $50-60 \%$ and the average pore size is $0.3 \mu \mathrm{m}$ [27]. After dip-coating with 3 and $6 \mathrm{wt} \%$ Pebax ${ }^{\circledR} 2533$ solutions, a defect-free Pebax ${ }^{\circledR} 2533$ 
selective layer was fabricated on the shell side of PP hollow fiber support (Figure 7B). When UiO-66- $\mathrm{NH}_{2}$ was incorporated into the Pebax ${ }^{\circledR} 2533$ matrix, the thin film mixed matrix membrane was successfully formed on the outer surface of PP hollow fiber support (Figure 7C-G). The loading amount of UiO-66- $\mathrm{NH}_{2}$ nanoparticles did not influence the thickness of Pebax ${ }^{\circledR}$ 2533-UiO-66- $\mathrm{NH}_{2}$ hybrid selective layer since the coating Pebax ${ }^{\circledR} 2533$ solution was kept constant at $6 \mathrm{wt} \%$. The thickness of the Pebax ${ }^{\circledR} 2533-\mathrm{UiO}-66-\mathrm{NH}_{2}$ hybrid selective layer was in the range of 5.40-6.97 $\mu \mathrm{m}$ (Table S2). When comparing the morphology of the prepared hollow fiber membranes, the roughness of the shell side increased with the increase of the UiO-66- $\mathrm{NH}_{2}$ content from 0 to $50 \mathrm{wt} \%$ (Figure 7B4-G4). When the content of UiO-66- $\mathrm{NH}_{2}$ was low (5 and $10 \mathrm{wt} \%$ ), the homogeneous dispersion of UiO-66- $\mathrm{NH}_{2}$ particles into Pebax ${ }^{\circledR} 2533$ matrix was observed (Figure 7B,C). At the high content of MOF particles $(15,20$, and $50 \mathrm{wt} \%)$, the aggregation of $\mathrm{UiO}-66-\mathrm{NH}_{2}$ in the polymeric matrix was observed (Figure 7E-G and Figure S2). It is reported that the MOF aggregation in polymeric matrix could lead to the formation of non-selective defects during the fabrication process [36]. Similar phenomenon was observed by Sutrisna et al. [33]. In their work, Pebax ${ }^{\circledR}$ 1657-UiO-66/PVDF thin film mixed matrix hollow fiber membranes were prepared for $\mathrm{CO}_{2}$ separation. When the filler content was in the range of $10-50 \mathrm{wt} \%$, no significantly aggregation was observed. However, the significant UiO-66 particle aggregation was observed when $80 \mathrm{wt} \%$ of UiO-66 was incorporated into the Pebax ${ }^{\circledR} 1657$ matrix [33].

To investigate the chemical structure of pure PP hollow fiber support and the prepared thin film mixed matrix hollow fiber membranes, FTIR analysis was conducted. The FTIR spectra of PP hollow fiber support and the prepared Pebax ${ }^{\circledR} 2533-\mathrm{UiO}-66-\mathrm{NH}_{2} / \mathrm{PP}$ thin film mixed matrix hollow fiber membranes in the range of $650-4000 \mathrm{~cm}^{-1}$ were shown in Figure 8. As the FTIR spectra of PP shows, the peak at $841 \mathrm{~cm}^{-1}$ was attributed to $\mathrm{C}-\mathrm{CH}_{3}$ stretching vibration. The peaks at 973,998 , and $1168 \mathrm{~cm}^{-1}$ were attributed to $-\mathrm{CH}_{3}$ rocking vibration. The symmetric bending vibration of $-\mathrm{CH}_{3}$ group was observed at $1376 \mathrm{~cm}^{-1}$. The $-\mathrm{CH}_{3}$ asymmetric stretching vibration was observed at $2951 \mathrm{~cm}^{-1}$. Besides the peaks related to methyl group in PP, the peaks at 1456, 2839, and $2919 \mathrm{~cm}^{-1}$ are designated to $-\mathrm{CH}_{2}-$ symmetric bending, $-\mathrm{CH}_{2}-$ symmetric stretching and $-\mathrm{CH}_{2}-$ asymmetric stretching, respectively. Our FTIR results are in good agreement with the literature values [37,38]. After the formation of Pebax ${ }^{\circledR} 2533$ layer on the shell side of PP hollow fiber support, the characteristic peaks of the $-\mathrm{CH}_{3}$ group from PP disappeared. The characteristic peaks at $1109,1640,1734$, and $3308 \mathrm{~cm}^{-1}$, are assigned to the stretching vibration of the $\mathrm{C}-\mathrm{O}-\mathrm{C}$ group of the $\mathrm{PEO}$ segment part, the $\mathrm{N}-\mathrm{H}-\mathrm{C}=\mathrm{O}$ stretching vibration, the $-\mathrm{O}-\mathrm{C}=\mathrm{O}$ group, and the $-\mathrm{N}-\mathrm{H}-$ stretching vibration of the polyamide block in Pebax ${ }^{\circledR}$ 2533 , respectively $[33,39]$. The FTIR spectra of the prepared Pebax ${ }^{\circledR}$ 2533-UiO-66- $\mathrm{NH}_{2} / \mathrm{PP}$ thin film mixed matrix hollow fiber membranes are similar to the FTIR spectra of pristine Pebax ${ }^{\circledR}$ 2533/PP hollow fiber membranes, which demonstrates that there were no strong chemical interaction between UiO-66- $\mathrm{NH}_{2}$ fillers and Pebax ${ }^{\circledR} 2533$ matrix. It was found that the red shift of FTIR characteristic peak related to the $-\mathrm{N}-\mathrm{H}$ - stretching vibration occurred when the UiO-66- $\mathrm{NH}_{2}$ particles were incorporated into Pebax ${ }^{\circledR} 2533$ due to the formation of hydrogen bonding $[14,40]$. However, the peaks related to the $-\mathrm{N}-\mathrm{H}-$ stretching vibration for the mixed matrix membrane containing $0,5,10,15,20$, and $50 \mathrm{wt} \%$ of $\mathrm{UiO}-66-\mathrm{NH}_{2}$ are $3308,3297,3297,3296,3307$, and $3307 \mathrm{~cm}^{-1}$, respectively (Figure 8A). The $-\mathrm{N}-\mathrm{H}-$ peak shift for PA (polyamide) segment is negligible due to the difficulty in the thin composite layer characterization [33]. As it is shown in the FTIR spectra in the range of 700-800 $\mathrm{cm}^{-1}$ (Figure $8 \mathrm{C}$ ), a peak related to the stretching vibration of $\mathrm{Zr}-\mathrm{O}$ bond around $764 \mathrm{~cm}^{-1}$ was observed, which indicates the serious aggregation of $\mathrm{UiO}-66-\mathrm{NH}_{2}$ particles in the mixed matrix hollow fiber membranes. This finding is in good agreement with the SEM results (Figure 7G). 


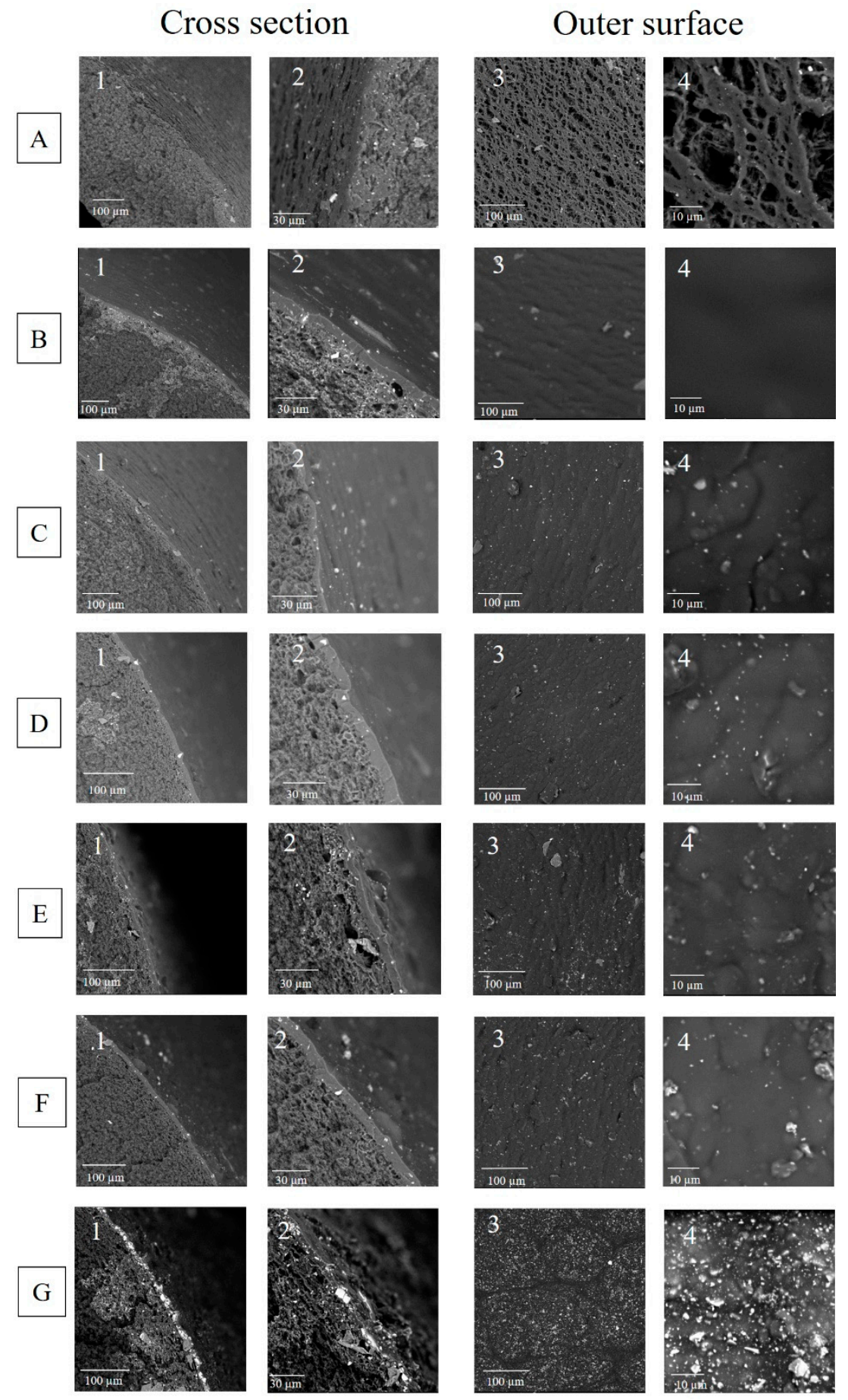

Figure 7. SEM pictures of cross-section (1 and 2) and outer surface ( 3 and 4$)$ of Pebax ${ }^{\circledR} 2533-U i O-66-$ $\mathrm{NH}_{2} / \mathrm{PP}$ thin film mixed matrix hollow fiber membranes-(A) PP hollow fiber support, (B) $0 \mathrm{wt} \%$ UiO-66- $\mathrm{NH}_{2}$, (C) $5 \mathrm{wt} \%$ UiO-66- $\mathrm{NH}_{2}$, (D) $10 \mathrm{wt} \% \mathrm{UiO}-66-\mathrm{NH}_{2}$, (E) $15 \mathrm{wt} \%$ UiO-66-NH $\mathrm{N}_{2}$, (F) $20 \mathrm{wt} \%$ $\mathrm{UiO}-66-\mathrm{NH}_{2}$, and (G) $50 \mathrm{wt} \% \mathrm{UiO}-66-\mathrm{NH}_{2}$. 


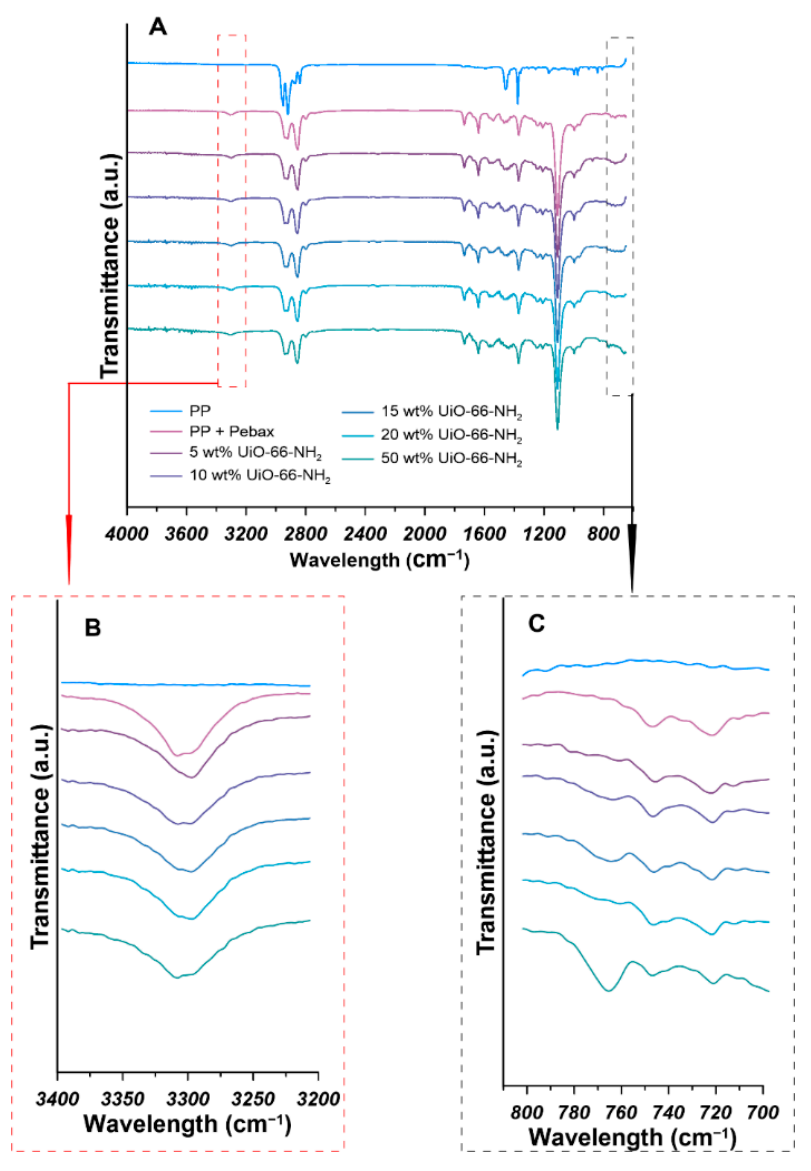

Figure 8. FTIR (Fourier transform infrared) spectra of Pebax ${ }^{\circledR}$ 2533-UiO-66- $\mathrm{NH}_{2} / \mathrm{PP}$ thin film mixed matrix hollow fiber membranes (A) (the enlarged FTIR spectra in the wavelength range $3400-3200 \mathrm{~cm}^{-1}$ and $800-700 \mathrm{~cm}^{-1}$ are shown in (B) and (C), respectively).

\subsection{The Effect of UiO-66- $\mathrm{NH}_{2}$ Loading on Gas Separation Performance}

The gas separation behaviors of the prepared thin film mixed matrix hollow fiber membranes were studied by the gas permeation measurements. The $\mathrm{CO}_{2}$ and $\mathrm{N}_{2}$ permeance through the prepared membranes were measured at 2 bar and $25^{\circ} \mathrm{C}$. As it is shown in Figure 9, the UiO-66- $\mathrm{NH}_{2}$ content in the Pebax ${ }^{\circledR} 2533$ matrix influenced the gas permeance and the ideal selectivity of Pebax ${ }^{\circledR}$ 2533-UiO-66- $\mathrm{NH}_{2} / \mathrm{PP}$ thin film mixed matrix hollow fiber membranes. As can be seen from Figure 9A, when the UiO-66- $\mathrm{NH}_{2}$ content increased from 0 to $50 \mathrm{wt} \%$, the $\mathrm{CO}_{2}$ permeance increased significantly from 19 to $30 \mathrm{GPU}$. The $\mathrm{N}_{2}$ permeance barely increased when the $\mathrm{UiO}-66-\mathrm{NH}_{2}$ content increased from 0 to $10 \mathrm{wt} \%$. However, the $\mathrm{N}_{2}$ permeance increased to $0.91,1.14$, and $1.42 \mathrm{GPU}$ when the UiO- $66-\mathrm{NH}_{2}$ content increased to 15, 20, and $50 \mathrm{wt} \%$, respectively. As it is shown in Figure $9 \mathrm{~B}$, the $\mathrm{CO}_{2} / \mathrm{N}_{2}$ ideal selectivity firstly increased from 30 to 37 when the UiO-66- $\mathrm{NH}_{2}$ content increased from 0 to $10 \mathrm{wt} \%$. Then the $\mathrm{CO}_{2} / \mathrm{N}_{2}$ ideal selectivity decreased to 21 when the UiO-66- $\mathrm{NH}_{2}$ content increased to $50 \mathrm{wt} \%$. 

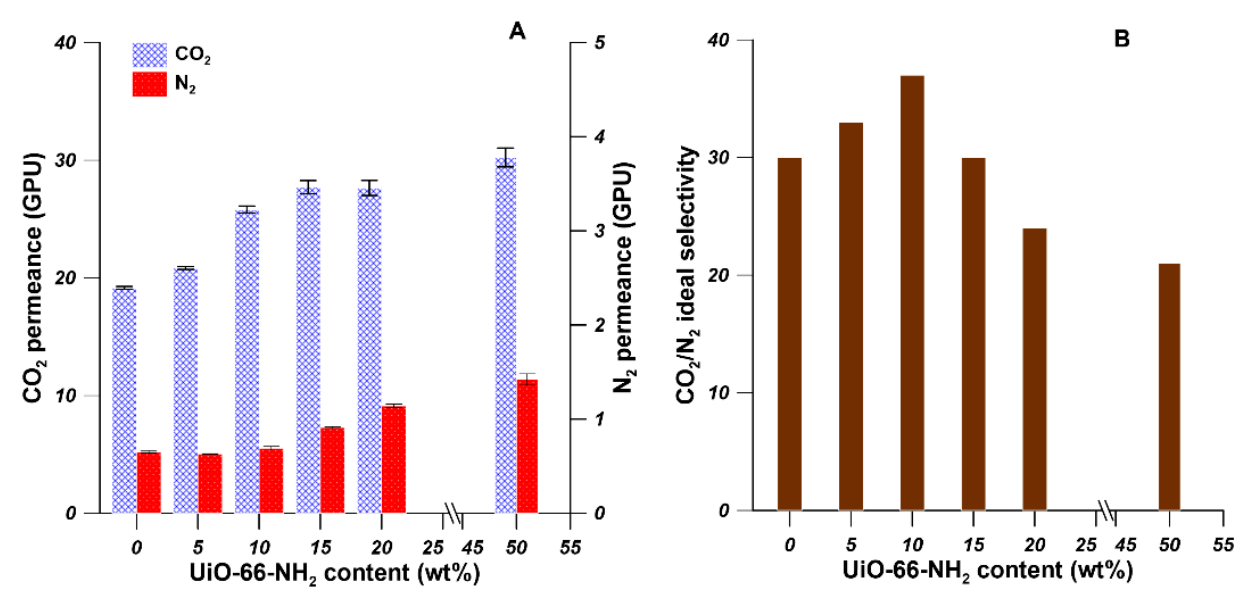

Figure 9. The effect of $\mathrm{UiO}-66-\mathrm{NH}_{2}$ content on the $\mathrm{CO}_{2}$ and $\mathrm{N}_{2}$ permeances $(\mathrm{A})$ and $\mathrm{CO}_{2} / \mathrm{N}_{2}$ ideal selectivity (B) of Pebax ${ }^{\circledR}$ 2533-UiO-66- $\mathrm{NH}_{2} / \mathrm{PP}$ thin film mixed matrix hollow fiber membranes.

As discussed above, when the UiO- $66-\mathrm{NH}_{2}$ content increased to $10 \mathrm{wt} \%$, both the $\mathrm{CO}_{2}$ permeance and $\mathrm{CO}_{2} / \mathrm{N}_{2}$ ideal selectivity increased while the $\mathrm{N}_{2}$ permeance was practically unchanged, which indicates the formation of defect-free thin mixed matrix membrane on the PP hollow fiber support. The enhanced $\mathrm{CO}_{2}$ permeance and $\mathrm{CO}_{2} / \mathrm{N}_{2}$ ideal selectivity were ascribed to the interrupted chain packing in the polymer matrix [41] and the $\mathrm{CO}_{2}$-philic nature of $\mathrm{UiO}-66-\mathrm{NH}_{2}$ [42]. In comparison to the pure Pebax ${ }^{\circledR} 2533$ thin film hollow fiber membrane, the $\mathrm{CO}_{2}$ permeance and $\mathrm{CO}_{2} / \mathrm{N}_{2}$ ideal selectivity of Pebax ${ }^{\circledR}$ 2533-UiO-66- $\mathrm{NH}_{2} / \mathrm{PP}$ thin film mixed matrix hollow fiber membrane containing $10 \mathrm{wt} \%$ UiO-66- $-\mathrm{NH}_{2}$ increased by 35 and $23 \%$, respectively. The kinetic diameters for $\mathrm{CO}_{2}$ and $\mathrm{N}_{2}$ molecules are 0.33 and $0.36 \mathrm{~nm}$, respectively. The $\mathrm{CO}_{2}$ mobility is higher than the $\mathrm{N}_{2}$ mobility in Pebax ${ }^{\circledR}$ membranes due to smaller size and higher condensability of $\mathrm{CO}_{2}$ molecules, and the $\mathrm{CO}_{2}$-philic ether group in Pebax ${ }^{\circledR}$ polymer chains [14]. The $\mathrm{CO}_{2}$ permeance increased with the addition of $\mathrm{UiO}-66-\mathrm{NH}_{2}$ nanoparticles. The $\mathrm{N}_{2}$ permeance increased slightly when the $\mathrm{UiO}-66-\mathrm{NH}_{2}$ content increased from 0 to $10 \mathrm{wt} \%$. However, when the UiO-66- $\mathrm{NH}_{2}$ content was higher than $10 \mathrm{wt} \%$, the $\mathrm{N}_{2}$ permeance started to increase significantly, resulting in the decrease in $\mathrm{CO}_{2} / \mathrm{N}_{2}$ ideal selectivity. For instance, when 20 and $50 \mathrm{wt} \%$ of UiO-66- $\mathrm{NH}_{2}$ was incorporated into the Pebax ${ }^{\circledR} 2533$ matrix, the $\mathrm{CO}_{2}$ permeance increased $9 \%$ while the $\mathrm{N}_{2}$ permeance increased $25 \%$. Consequently, the $\mathrm{CO}_{2} / \mathrm{N}_{2}$ ideal selectivity was less than that of pure Pebax ${ }^{\circledR} 2533$ membranes. This can be explained by the severe agglomeration of UiO-66- $\mathrm{NH}_{2}$ when large amounts of UiO-66- $\mathrm{NH}_{2}$ particles were incorporated into polymeric matrix. Consequently, the nonselective interface defects were formed, resulting in the deterioration of gas separation of Pebax ${ }^{\circledR} 2533-\mathrm{UiO}-66-\mathrm{NH}_{2} / \mathrm{PP}$ thin film mixed matrix hollow fiber membranes. The agglomeration of nanoparticles in the mixed matrix membranes have been documented in the literature [14,41,43]. Shen et al. [14] prepared Pebax ${ }^{\circledR} 1657$ based mixed matrix membranes containing UiO-66 and UiO-66- $\mathrm{NH}_{2}$ nanoparticles for $\mathrm{CO}_{2}$ separation. It was found that $\mathrm{CO}_{2} / \mathrm{N}_{2}$ selectivity started to decrease due to the filler agglomeration when the UiO-66 and UiO-66- $\mathrm{NH}_{2}$ loading is higher than 7.5 and $10 \mathrm{wt} \%$, respectively. Jiao et al. [43] synthesized polyethyleneimine (PEI) modified ZIF-8 and incorporated the PEI-ZIF-8 particle into Pebax ${ }^{\circledR} 1657$ matrix to prepare mixed matrix membranes for $\mathrm{CO}_{2} / \mathrm{N}_{2}$ separation. It was found that the composite membrane with $5 \mathrm{wt} \%$ PEI-ZIF-8 shows the best gas separation performance with $\mathrm{CO}_{2}$ permeance equal to $13 \mathrm{GPU}$ and $\mathrm{CO}_{2} / \mathrm{N}_{2}$ selectivity equal to 49 . The filler agglomeration occurred resulting in rigidified interface.

\subsection{Comparison of the Pebax ${ }^{\circledR}$-Based Mixed Matrix Membranes Incorporating Various Nanoparticles in $\mathrm{CO}_{2} / \mathrm{N}_{2}$ Gas Separation}

The performance of the prepared Pebax ${ }^{\circledR}$ 2533-UiO-66- $\mathrm{NH}_{2} / \mathrm{PP}$ thin film mixed matrix hollow fiber membranes were compared with Pebax ${ }^{\circledR}$-based mixed matrix membranes 
containing various types of fillers (Table 1 ). The gas separation performance of Pebax ${ }^{\circledR}$ 2533-UiO-66- $\mathrm{NH}_{2} / \mathrm{PP}$ thin film mixed matrix hollow fiber membrane containing $10 \mathrm{wt} \%$ UiO-66- $\mathrm{NH}_{2}$ is comparable with previous reported Pebax ${ }^{\circledR}$-based mixed matrix membranes containing various types of fillers in literature [14,33,40,44-52]. The prepared membrane shows a high $\mathrm{CO}_{2} / \mathrm{N}_{2}$ ideal selectivity equal to 37 with a $\mathrm{CO}_{2}$ permeance $25.81 \mathrm{GPU}$ at feed pressure 2 bar. The addition of $\mathrm{UiO}-66-\mathrm{NH}_{2}$ enhances the $\mathrm{CO}_{2} / \mathrm{N}_{2}$ separation performance mainly due to the good interfacial compatibility and the $\mathrm{CO}_{2}$-philic nature of UiO-66- $\mathrm{NH}_{2}$. Sutrisna et al. [33] fabricated UiO-66- $\mathrm{NH}_{2} /$ Pebax $^{\circledR} 1657$ based hollow fiber composite membranes with high $\mathrm{CO}_{2}$ permeance equal to $338 \mathrm{GPU}$ and high $\mathrm{CO}_{2} / \mathrm{N}_{2}$ selectivity equal to 57 . Their work showed better $\mathrm{CO}_{2} / \mathrm{N}_{2}$ separation performance, which can be attributed to the lower Pebax ${ }^{\circledR} 1657$ coating solution, and the application of poly [1-(trimethylsilyl) prop-1-yne] (PTMSP) as a gutter layer. The lower coating solution concentration could result in smaller selective layer thickness. The smooth PTMSP gutter layer can prevent the intrusion of Pebax ${ }^{\circledR}$ into pores of support layer, resulting in a thin selective layer. As a result, the prepared UiO-66- $\mathrm{NH}_{2} /$ Pebax ${ }^{\circledR} 1657$ based hollow fiber composite membranes showed very high gas separation performance. As it is shown in Table 1, the thin film mixed matrix membranes possess comparable $\mathrm{CO}_{2} / \mathrm{N}_{2}$ selectivity but much higher $\mathrm{CO}_{2}$ permeance than that of dense flat sheet mixed matrix membranes. Therefore, the gas separation performances of thin film mixed matrix membranes are better than the dense flat sheet membranes.

Table 1. The comparison of gas separation performances of Pebax ${ }^{\circledR}$-based mixed matrix membranes with different fillers.

\begin{tabular}{|c|c|c|c|c|c|c|c|c|}
\hline $\begin{array}{l}\text { Support } \\
\text { Polymer }\end{array}$ & $\begin{array}{l}\text { Hybrid Coating } \\
\text { Material }\end{array}$ & $\begin{array}{c}\text { Filler } \\
\text { Content } \\
(w t \%)\end{array}$ & Configuration & Feed Gas & $\begin{array}{l}\mathrm{CO}_{2} \\
\text { (GPU) }\end{array}$ & $\begin{array}{l}\mathrm{N}_{2} \\
\text { (GPU) }\end{array}$ & $\begin{array}{c}\mathrm{CO}_{2} / \mathrm{N}_{2} \\
\text { Selectivity }\end{array}$ & Ref. \\
\hline PVDF/PTMSP & UiO-66-NH ${ }_{2} /$ Pebax $^{\circledR} 1657$ & 50 & Hollow fiber & Pure gas & 338 & 5.93 & 57 & [33] \\
\hline PSF & $\mathrm{Fe}(\mathrm{DA}) / \mathrm{Pebax}^{\circledR} 1657$ & 3 & Hollow fiber & Pure gas & 90.00 & 1.61 & 56 & [44] \\
\hline PVDF & ZIF-8/Pebax ${ }^{\circledR} 1657$ & 30 & Hollow fiber & Pure gas & 350.00 & 10.94 & 32 & [40] \\
\hline PVDF & GO/Pebax ${ }^{\circledR} 1657$ & 0.1 & Hollow fiber & Pure gas & 415.00 & 9.65 & 43 & [46] \\
\hline PSF & GO/Pebax ${ }^{\circledR} 1657$ & 0.4 & Hollow fiber & Pure gas & 28.08 & 0.66 & 43 & [47] \\
\hline PAN & ZIF-7/Pebax ${ }^{\circledR} 1657$ & 34 & Flat sheet & Pure gas & 39.00 & 0.37 & 105 & [45] \\
\hline PVDF & UiO-66-NH ${ }_{2} /$ Pebax $^{\circledR} 1657$ & 20 & Flat sheet & Pure gas & 125 Barrer & - & 25 & [14] \\
\hline- & ZIF-8/Pebax ${ }^{\circledR} 1657$ & 20 & $\begin{array}{l}\text { Dense flat } \\
\text { sheet }\end{array}$ & Pure gas & 2.80 & 0.07 & 41 & [48] \\
\hline- & $\mathrm{NH}_{2}$-MIL-53/Pebax ${ }^{\circledR} 1657$ & 10 & $\begin{array}{l}\text { Dense flat } \\
\text { sheet }\end{array}$ & Pure gas & 1.60 & 0.03 & 55 & [49] \\
\hline- & $\mathrm{NaY} / \mathrm{Pebax}^{\circledR} 1657$ & 10 & $\begin{array}{l}\text { Dense flat } \\
\text { sheet }\end{array}$ & Pure gas & 3.60 & 0.10 & 35 & [50] \\
\hline- & ZIF-7/Pebax ${ }^{\circledR} 2533$ & 14 & $\begin{array}{l}\text { Dense flat } \\
\text { sheet }\end{array}$ & Pure gas & 198 Barrer & 8.74 Barrer & 22.6 & [19] \\
\hline- & ZIF-7-NH $2 /$ Pebax $^{\circledR} 2533$ & 14 & $\begin{array}{l}\text { Dense flat } \\
\text { sheet }\end{array}$ & Pure gas & 206 Barrer & 7.53 Barrer & 27.3 & [19] \\
\hline- & ZIF-8@GO/Pebax ${ }^{\circledR} 2533$ & 6 & $\begin{array}{l}\text { Dense flat } \\
\text { sheet }\end{array}$ & Pure gas & 249 Barrer & 5.23 Barrer & 47.6 & [51] \\
\hline- & Zn/Ni-ZIF-8/Pebax ${ }^{\circledR} 2533$ & 10 & $\begin{array}{l}\text { Dense flat } \\
\text { sheet }\end{array}$ & Pure gas & 321 Barrer & $\begin{array}{c}7.5 \\
\text { Barrer }\end{array}$ & 42.8 & [52] \\
\hline PP & UiO-66-NH $2 /$ Pebax $^{\circledR} 2533$ & 10 & Hollow fiber & Pure gas & 25.81 & 0.69 & 37 & $\begin{array}{l}\text { This } \\
\text { work }\end{array}$ \\
\hline
\end{tabular}

PVDF—polyvinylidene difluoride, PTMSP—poly [1-(trimethylsilyl) prop-1-yne], PSF—polysulfone, PAN—polyacrylonitrile, PP— polypropylene.

\section{Conclusions}

Pebax ${ }^{\circledR}$ 2533-UiO-66- $\mathrm{NH}_{2}$ /PP mixed matrix thin film hollow fiber membranes were successfully fabricated by using dip coating method. The pre-treatment of PP hollow fibers by dip-coating with $3 \mathrm{wt} \%$ Pebax $^{\circledR} 2533$ solution could smoothen the outer surface of hollow fiber supports, which facilitated the formation of defect-free selective layer. The incorporation of UiO-66- $\mathrm{NH}_{2}$ nanoparticles into the Pebax ${ }^{\circledR} 2533$ coating solution affected the morphology, surface chemistry, and gas separation performance of Pebax ${ }^{\circledR} 2533-\mathrm{UiO}-66-$ $\mathrm{NH}_{2}$ /PP mixed matrix thin film hollow fiber membranes confirmed by SEM analysis, FTIR analysis, and gas permeance measurements, respectively. The aggregation of UiO-66- $\mathrm{NH}_{2}$ 
nanoparticles was observed at higher amounts of $\mathrm{UiO}-66-\mathrm{NH}_{2}$ nanoparticles in the Pebax ${ }^{\circledR}$ 2533 matrix. The filler aggregation should be tackled by post-synthetic modification of $\mathrm{UiO}-66-\mathrm{NH}_{2}$ nanoparticles. The $\mathrm{CO}_{2}$ permeance increased with the increase of the loading amount of UiO-66 nanoparticles, while the $\mathrm{CO}_{2} / \mathrm{N}_{2}$ ideal gas selectively firstly increased then decreased due to the aggregation of UiO-66 nanoparticles. The Pebax ${ }^{\circledR} 2533-\mathrm{UiO}-$ 66- $\mathrm{NH}_{2} / \mathrm{PP}$ mixed matrix thin film hollow fiber membranes containing $10 \mathrm{wt} \% \mathrm{UiO}-66$ nanoparticles exhibited the best gas separation performance with $\mathrm{CO}_{2}$ permeance of 26 GPU and $\mathrm{CO}_{2} / \mathrm{N}_{2}$ selectivity of 37 .

Supplementary Materials: The following are available online at https:/ / www.mdpi.com/article/ 10.3390/ma14123366/s1, Figure S1: Hollow fiber module for testing gas permeance of hollow fiber membranes (This module is designed by the Membranes and Membrane Techniques Research Group in Nicolaus Copernicus University in Torun. All the components of this module including housing part, end caps, and ports are purchased from Swagelok), Figure S2: The Zr element mapping and

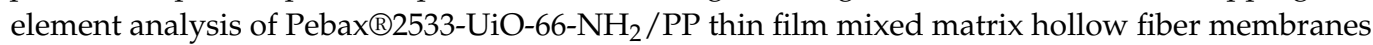
by EDX. (a) $15 \mathrm{wt} \%$ UiO-66- $\mathrm{NH}_{2}$, (b) $20 \mathrm{wt} \% \mathrm{UiO}-66-\mathrm{NH}_{2}$, (c) $50 \mathrm{wt} \% \mathrm{UiO}-66-\mathrm{NH}_{2}$, Table S1: The gas permeance and ideal selectivity of thin film hollow fiber membranes fabricated from single concentration of coating solution, Table S2: The thickness of the Pebax/UiO-66-NH2 hybrid layer measured from the top part and bottom part of the prepared mixed matrix thin film hollow fiber membrane. The bottom part is close to the coating solution while the top part is close to the metal holder during the dip-coating process.

Author Contributions: Conceptualization, G.L. and W.K.; Data curation, G.L. and K.K.; Formal analysis, G.L., W.K., K.K. and J.K.; Funding acquisition, G.L. and W.K.; Investigation, G.L.; Methodology, G.L., W.K. and J.K.; Resources, W.K.; Software, K.K. and J.K.; Supervision, W.K. and J.K.; Validation, G.L.; Visualization, G.L. and K.K.; Writing—original draft, G.L.; Writing—review \& editing, G.L., W.K. and K.K. All authors have read and agreed to the published version of the manuscript.

Funding: This work was supported by the Young Researcher grant for PhD Students of Nicolaus Copernicus University in Torun, Poland (Faculty of Chemistry, 492/2020).

Institutional Review Board Statement: Not applicable.

Informed Consent Statement: Not applicable.

Data Availability Statement: The data presented in this study are available on request from the corresponding author.

Conflicts of Interest: The authors declare no conflict of interest.

\section{References}

1. Al Mesfer, M.K.; Danish, M. Breakthrough adsorption study of activated carbons for $\mathrm{CO}_{2}$ separation from flue gas. J. Environ. Chem. Eng. 2018, 6, 4514-4524. [CrossRef]

2. Wang, K.; Xu, H.; Yang, C.; Qiu, T. Machine learning-based ionic liquids design and process simulation for $\mathrm{CO}_{2}$ separation from flue gas. Green Energy Environ. 2020. [CrossRef]

3. Polat, H.M.; Kavak, S.; Kulak, H.; Uzun, A.; Keskin, S. $\mathrm{CO}_{2}$ separation from flue gas mixture using [BMIM][BF4]/MOF com-posites: Linking high-throughput computational screening with experiments. Chem. Eng. J. 2020, 394, 124916. [CrossRef]

4. Gilassi, S.; Taghavi, S.M.; Rodrigue, D.; Kaliaguine, S. Techno-Economic Analysis of a Hybrid System for Flue-Gas Separa-tion: Combining Membrane and Enzymatic-Absorption Processes. Chem. Eng. Process. Process. Intensif. 2021, 159, 108222. [CrossRef]

5. Kamble, A.R.; Patel, C.M.; Murthy, Z. A review on the recent advances in mixed matrix membranes for gas separation processes. Renew. Sustain. Energy Rev. 2021, 145, 111062. [CrossRef]

6. Li, G.; Kujawski, W.; Válek, R.; Koter, S. A review-The development of hollow fibre membranes for gas separation processes. Int. J. Greenh. Gas. Control. 2021, 104, 103195. [CrossRef]

7. Li, G.; Kujawski, W.; Knozowska, K.; Kujawa, J. The Effects of PEI Hollow Fiber Substrate Characteristics on PDMS/PEI Hollow Fiber Membranes for $\mathrm{CO}_{2} / \mathrm{N}_{2}$ Separation. Membranes 2021, 11, 56. [CrossRef]

8. Li, G.; Knozowska, K.; Kujawa, J.; Tonkonogovas, A.; Stankevičius, A.; Kujawski, W. Fabrication of Polydimethysiloxane (PDMS) Dense Layer on Polyetherimide (PEI) Hollow Fiber Support for the Efficient $\mathrm{CO}_{2} / \mathrm{N}_{2}$ Separation Membranes. Polymers 2021, 13, 756. [CrossRef] [PubMed]

9. Liu, B.; Tang, C.; Li, X.; Wang, B.; Zhou, R. High-performance SAPO-34 membranes for $\mathrm{CO}_{2}$ separations from simulated flue gas. Microporous Mesoporous Mater. 2020, 292, 109712. [CrossRef] 
10. Ilicak, I.; Boroglu, M.S.; Durmus, A.; Boz, I. Influence of ZIF-95 on structure and gas separation properties of polyi-mide-based mixed matrix membranes. J. Nat. Gas. Sci. Eng. 2021, 91, 103941. [CrossRef]

11. Wang, Q.; Dai, Y.; Ruan, X.; Zheng, W.; Yan, X.; Li, X.; He, G. ZIF-8 hollow nanotubes based mixed matrix membranes with high-speed gas transmission channel to promote $\mathrm{CO}_{2} / \mathrm{N}_{2}$ separation. J. Membr. Sci. 2021, 630, 119323. [CrossRef]

12. Saqib, S.; Rafiq, S.; Muhammad, N.; Khan, A.L.; Mukhtar, A.; Ullah, S.; Nawaz, M.H.; Jamil, F.; Zhang, C.; Ashokkumar, V. Sustainable mixed matrix membranes containing porphyrin and polysulfone polymer for acid gas separations. J. Hazard. Mater. 2021, 411, 125155. [CrossRef]

13. Liu, L.; Chakma, A.; Feng, X. $\mathrm{CO}_{2} / \mathrm{N}_{2}$ Separation by Poly(Ether Block Amide) Thin Film Hollow Fiber Composite Membranes. Ind. Eng. Chem. Res. 2005, 44, 6874-6882. [CrossRef]

14. Shen, J.; Liu, G.; Huang, K.; Li, Q.; Guan, K.; Li, Y.; Jin, W. UiO-66-polyether block amide mixed matrix membranes for $\mathrm{CO}_{2}$ separation. J. Membr. Sci. 2016, 513, 155-165. [CrossRef]

15. Casadei, R.; Baschetti, M.G.; Yoo, M.J.; Park, H.B.; Giorgini, L. Pebax ${ }^{\circledR}$ 2533/Graphene Oxide Nanocomposite Membranes for Carbon Capture. Membranes 2020, 10, 188. [CrossRef] [PubMed]

16. Liu, C.; Wang, J.; Wan, J.; Yu, C. MOF-on-MOF hybrids: Synthesis and applications. Co-Ord. Chem. Rev. 2021, $432,213743$. [CrossRef]

17. Chen, S.; Li, X.; Duan, J.; Fu, Y.; Wang, Z.; Zhu, M.; Li, N. Investigation of highly efficient adsorbent based on Ni-MOF-74 in the separation of $\mathrm{CO}_{2}$ from natural gas. Chem. Eng. J. 2021, 419, 129653. [CrossRef]

18. Kujawa, J.; Al-Gharabli, S.; Muzioł, T.M.; Knozowska, K.; Li, G.; Dumée, L.F.; Kujawski, W. Crystalline porous frameworks as nano-enhancers for membrane liquid separation-Recent developments. Co-Ord. Chem. Rev. 2021, 440, 213969. [CrossRef]

19. Gao, J.; Mao, H.; Jin, H.; Chen, C.; Feldhoff, A.; Li, Y. Functionalized ZIF-7/Pebax ${ }^{\circledR} 2533$ mixed matrix membranes for $\mathrm{CO}_{2} / \mathrm{N}_{2}$ separation. Microporous Mesoporous Mater. 2020, 297, 110030. [CrossRef]

20. Song, C.; Li, R.; Fan, Z.; Liu, Q.; Zhang, B.; Kitamura, Y. $\mathrm{CO}_{2} / \mathrm{N}_{2}$ separation performance of Pebax/MIL-101 and Pebax / $\mathrm{NH}_{2}$-MIL-101 mixed matrix membranes and intensification via sub-ambient operation. Sep. Purif. Technol. 2020, 238, 116500. [CrossRef]

21. Chuah, C.Y.; Lee, J.; Song, J.; Bae, T.-H. $\mathrm{CO}_{2} / \mathrm{N}_{2}$ Separation Properties of Polyimide-Based Mixed-Matrix Membranes Comprising UiO-66 with Various Functionalities. Membranes 2020, 10, 154. [CrossRef] [PubMed]

22. Jiang, Y.; Liu, C.; Caro, J.; Huang, A. A new UiO-66- $\mathrm{NH}_{2}$ based mixed-matrix membranes with high $\mathrm{CO}_{2} / \mathrm{CH}_{4}$ separation performance. Microporous Mesoporous Mater. 2019, 274, 203-211. [CrossRef]

23. Jameh, A.A.; Mohammadi, T.; Bakhtiari, O. Preparation of PEBAX-1074/modified ZIF-8 nanoparticles mixed matrix membranes for $\mathrm{CO}_{2}$ removal from natural gas. Sep. Purif. Technol. 2020, 231, 115900. [CrossRef]

24. Dai, Y.; Johnson, J.; Karvan, O.; Sholl, D.S.; Koros, W. Ultem ${ }^{\circledR} / \mathrm{ZIF}-8$ mixed matrix hollow fiber membranes for $\mathrm{CO}_{2} / \mathrm{N}_{2}$ separations. J. Membr. Sci. 2012, 401-402, 76-82. [CrossRef]

25. Etxeberria-Benavides, M.; Johnson, T.; Cao, S.; Zornoza, B.; Coronas, J.; Sanchez-Lainez, J.; Sabetghadam, A.; Liu, X.; AndresGarcia, E.; Kapteijn, F.; et al. PBI mixed matrix hollow fiber membrane: Influence of ZIF-8 filler over $\mathrm{H}_{2} / \mathrm{CO}_{2}$ separation performance at high temperature and pressure. Sep. Purif. Technol. 2020, 237, 116347. [CrossRef]

26. Xu, Z.-K.; Dai, Q.-W.; Liu, Z.-M.; Kou, R.-Q.; Xu, Y.-Y. Microporous polypropylene hollow fiber membranes: Part II. Per-vaporation separation of water/ethanol mixtures by the poly (acrylic acid) grafted membranes. J. Membr. Sci. 2003, 214, 71-81. [CrossRef]

27. Szwast, M.; Zalewski, M.; Prokopowicz, L.; Khoshgrudi, R.N. Novel Mixed Matrix Membrane for gas mixture separation. In Monographs of the Environmental Engineering Committee Polish Academy of Sciences: Membranes and Membrane Processes in Environmental Protection; Konieczny, K., Korus, I., Eds.; Polska Akademia Nauk, Komitet Inżynierii Środowiska: Warsaw, Poland, 2014; pp. 89-99.

28. Zhu, J.; Wu, L.; Bu, Z.; Jie, S.; Li, B.-G. Polyethyleneimine-Modified UiO-66- $\mathrm{NH}_{2}(\mathrm{Zr})$ Metal-Organic Frameworks: Preparation and Enhanced $\mathrm{CO}_{2}$ Selective Adsorption. ACS Omega 2009, 4, 3188-3197. [CrossRef]

29. Hou, J.; Luan, Y.; Tang, J.; Wensley, A.M.; Yang, M.; Lu, Y. Synthesis of UiO-66- $\mathrm{NH}_{2}$ derived heterogeneous copper (II) catalyst and study of its application in the selective aerobic oxidation of alcohols. J. Mol. Catal. A Chem. 2015, 407, 53-59. [CrossRef]

30. Zhang, X.; Zhang, Y.; Wang, T.; Fan, Z.; Zhang, G. A thin film nanocomposite membrane with pre-immobilized UiO-66-NH 2 toward enhanced nanofiltration performance. RSC Adv. 2019, 9, 24802-24810. [CrossRef]

31. Cao, Y.; Zhang, H.; Song, F.; Huang, T.; Ji, J.; Zhong, Q.; Chu, W.; Xu, Q. UiO-66-NH2/GO Composite: Synthesis, Characterization and $\mathrm{CO}_{2}$ Adsorption Performance. Materials 2018, 11, 589. [CrossRef]

32. Thommes, M.; Kaneko, K.; Neimark, A.V.; Olivier, J.P.; Rodriguez-Reinoso, F.; Rouquerol, J.; Sing, K.S.W. Physisorption of gases, with special reference to the evaluation of surface area and pore size distribution (IUPAC Technical Report). Pure Appl. Chem. 2015, 87, 1051-1069. [CrossRef]

33. Sutrisna, P.D.; Hou, J.; Zulkifli, M.Y.; Li, H.; Zhang, Y.; Liang, W.; D'Alessandro, D.M.; Chen, V. Surface functionalized UiO66/Pebax-based ultrathin composite hollow fiber gas separation membranes. J. Mater. Chem. A 2017, 6, 918-931. [CrossRef]

34. Tambat, S.N.; Sane, P.K.; Suresh, S.; Varadan, N.; Pandit, A.B.; Sontakke, S.M. Hydrothermal synthesis of $\mathrm{NH}_{2}-\mathrm{UiO}^{-66}$ and its application for adsorptive removal of dye. Adv. Powder Technol. 2018, 29, 2626-2632. [CrossRef]

35. Trickett, C.A.; Gagnon, K.J.; Lee, S.; Gándara, F.; Bürgi, H.-B.; Yaghi, O.M. Definitive Molecular Level Characterization of Defects in UiO-66 Crystals. Angew. Chem. Int. Ed. 2015, 54, 11162-11167. [CrossRef] [PubMed] 
36. Bi, X.; Zhang, Y.; Zhang, F.; Zhang, S.; Wang, Z.; Jin, J. MOF Nanosheet-Based Mixed Matrix Membranes with Metal-Organic Coordination Interfacial Interaction for Gas Separation. ACS Appl. Mater. Interfaces 2020, 12, 49101-49110. [CrossRef]

37. Gopanna, A.; Mandapati, R.N.; Thomas, S.P.; Rajan, K.; Chavali, M. Fourier transform infrared spectroscopy (FTIR), Raman spectroscopy and wide-angle X-ray scattering (WAXS) of polypropylene (PP)/cyclic olefin copolymer (COC) blends for qualitative and quantitative analysis. Polym. Bull. 2019, 76, 4259-4274. [CrossRef]

38. Gonzalez-Canche, N.G.; Flores-Johnson, E.A.; Cortes, P.; Carrillo, J.G. Evaluation of surface treatments on 5052-H32 aluminum alloy for enhancing the interfacial adhesion of thermoplastic-based fiber metal laminates. Int. J. Adhes. Adhes. 2018, 82, 90-99. [CrossRef]

39. Bernardo, P.; Clarizia, G. Enhancing Gas Permeation Properties of Pebax ${ }^{\circledR} 1657$ Membranes via Polysorbate Nonionic Surfactants Doping. Polymers 2020, 12, 253. [CrossRef] [PubMed]

40. Sutrisna, P.D.; Hou, J.; Li, H.; Zhang, Y.; Chen, V. Improved operational stability of Pebax-based gas separation membranes with ZIF-8: A comparative study of flat sheet and composite hollow fibre membranes. J. Membr. Sci. 2017, 524, 266-279. [CrossRef]

41. Nafisi, V.; Hägg, M.-B. Development of dual layer of ZIF-8/PEBAX-2533 mixed matrix membrane for $\mathrm{CO}_{2}$ capture. J. Membr. Sci. 2014, 459, 244-255. [CrossRef]

42. Biswas, S.P.; Van Der Voort, P. A General Strategy for the Synthesis of Functionalised UiO-66 Frameworks: Characterisation, Stability and $\mathrm{CO}_{2}$ Adsorption Properties. Eur. J. Inorg. Chem. 2013, 2013, 2154-2160. [CrossRef]

43. Jiao, C.; Li, Z.; Li, X.; Wu, M.; Jiang, H. Improved $\mathrm{CO}_{2} / \mathrm{N}_{2}$ separation performance of Pebax composite membrane containing polyethyleneimine functionalized ZIF-8. Sep. Purif. Technol. 2021, 259, 118190. [CrossRef]

44. Li, Y.; Wang, S.; Wu, H.; Wang, J.; Jiang, Z. Bioadhesion-inspired polymer-inorganic nanohybrid membranes with enhanced $\mathrm{CO}_{2}$ capture properties. J. Mater. Chem. 2012, 22, 19617-19620. [CrossRef]

45. Li, T.; Pan, Y.; Peinemann, K.-V.; Lai, Z. Carbon dioxide selective mixed matrix composite membrane containing ZIF-7 nano-fillers. J. Membr. Sci. 2013, 425-426, 235-242. [CrossRef]

46. Zhang, Y.; Shen, Q.; Hou, J.; Sutrisna, P.D.; Chen, V. Shear-aligned graphene oxide laminate/Pebax ultrathin composite hollow fiber membranes using a facile dip-coating approach. J. Mater. Chem. A 2017, 5, 7732-7737. [CrossRef]

47. Roslan, R.A.; Lau, W.J.; Lai, G.S.; Zulhairun, A.K.; Yeong, Y.F.; Ismail, A.F.; Matsuura, T. Impacts of Multilayer Hybrid Coating on PSF Hollow Fiber Membrane for Enhanced Gas Separation. Membranes 2020, 10, 335. [CrossRef] [PubMed]

48. Zheng, W.; Ding, R.; Yang, K.; Dai, Y.; Yan, X.; He, G. ZIF-8 nanoparticles with tunable size for enhanced $\mathrm{CO}_{2}$ capture of Pebax based MMMs. Sep. Purif. Technol. 2019, 214, 111-119. [CrossRef]

49. Meshkat, S.; Kaliaguine, S.; Rodrigue, D. Mixed matrix membranes based on amine and non-amine MIL-53(Al) in Pebax®MH-1657 for $\mathrm{CO}_{2}$ separation. Sep. Purif. Technol. 2018, 200, 177-190. [CrossRef]

50. Zheng, Y.; Wu, Y.; Zhang, B.; Wang, Z. Preparation and characterization of $\mathrm{CO}_{2}$-selective Pebax/NaY mixed matrix membranes. J Appl. Polym. Sci. 2020, 137, 48398. [CrossRef]

51. Dong, L.; Chen, M.; Li, J.; Shi, D.; Dong, W.; Li, X.; Bai, Y. Metal-organic framework-graphene oxide composites: A facile method to highly improve the $\mathrm{CO}_{2}$ separation performance of mixed matrix membranes. J. Membr. Sci. 2016, 520, 801-811. [CrossRef]

52. Zhang, X.; Zhang, T.; Wang, Y.; Li, J.; Liu, C.; Li, N.; Liao, J. Mixed-matrix membranes based on Zn/Ni-ZIF-8-PEBA for high performance $\mathrm{CO}_{2}$ separation. J. Membr. Sci. 2018, 560, 38-46. [CrossRef] 